Article

\title{
Screening of Lactobacillus plantarum subsp. plantarum with Potential Probiotic Activities for Inhibiting ETEC K88 in Weaned Piglets
}

\author{
Weiwei Wang ${ }^{1,2}{ }^{1}$, Hao Ma ${ }^{1,2}{ }^{,}$Haojie Yu ${ }^{1}$, Guangyong Qin ${ }^{1}$, Zhongfang Tan ${ }^{1}$, Yanping Wang ${ }^{1}$ \\ and Huili Pang 1,* \\ 1 Henan Key Lab Ion Beam Bioengineering, School of Agricultural Sciences, Zhengzhou University, \\ Zhengzhou 450052, China; wangwei508@foxmail.com (W.W.); mahaoworks@foxmail.com (H.M.); \\ haojie-yu@foxmail.com (H.Y.); qinguangyong@zzu.edu.cn (G.Q.); tzhongfang@zzu.edu.cn (Z.T.); \\ wyp@zzu.edu.cn (Y.W.) \\ 2 School of Physics and Microelectronics, Zhengzhou University, Zhengzhou 450052, China \\ * Correspondence: pang@zzu.edu.cn; Tel.: +86-150-3715-1053
}

Received: 14 August 2020; Accepted: 25 September 2020; Published: 29 September 2020

\begin{abstract}
For screening excellent lactic acid bacteria (LAB) strains to inhibit enterotoxigenic Escherichia coli (ETEC) K88, inhibitory activities of more than 1100 LAB strains isolated from different materials, and kept in the lab, were evaluated in this study. Nine strains with inhibition zones, at least $22.00 \mathrm{~mm}$ (including that of a hole puncher, $10.00 \mathrm{~mm}$ ), and good physiological and biochemical characteristics identified by 16S DNA gene sequencing and recA gene multiple detection, were assigned to Lactobacillus (L.) plantarum subsp. plantarum (5), L. fermentum (1), L. reuteri (1), Weissella cibaria (1) and Enterococcus faecalis (1), respectively. As investigated for their tolerance abilities and safety, only strain ZA3 possessed high hydrophobicity and auto-aggregation abilities, had high survival rate in low $\mathrm{pH}$, bile salt environment, and gastrointestinal (GI) fluids, was sensitive to ampicillin, and resistant to norfloxacin and amikacin, without hemolytic activity, and did not carry antibiotic resistance genes, but exhibited broad spectrum activity against a wide range of microorganisms. Antibacterial substance may attribute to organic acids, especially lactic acid and acetic acid. The results indicated that the selected strain L. plantarum subsp. plantarum ZA3 could be considered a potential probiotic to inhibit ETEC K88 in weaned piglets for further research.
\end{abstract}

Keywords: L. plantarum subsp. plantarum; ETEC K88; antimicrobial; probiotics

\section{Introduction}

Enterotoxigenic Escherichia coli (ETEC) K88 is a pathogenic variant of Escherichia coli that colonizes the surface of gastrointestinal cells when K88 infects the host and produces enterotoxins. This disrupts intestinal cellular electrolyte homeostasis, leading to fluid loss and, ultimately, to secretory diarrheal disease in newborns and piglets [1-3]. Post-weaning diarrhea (PWD) caused by ETEC K88 has a high mortality rate. In China and the United States, the average annual mortality of PWD cases is as high as $15 \%$ and $15.5 \%$, respectively, and the direct economic losses amount to more than US \$145 million [4]. Antibiotics have been long used to reduce diarrhea and enhance growth performance in weaned piglets, while long-term use of antibiotics caused the emergence of resistant strains of animal and food-borne pathogens and further intestinal microbial imbalance, according to announcement No. 194 of the Ministry of Agriculture and Rural Affairs. China officially stopped the production, import, operation, and use of some pharmaceutical feed additives as of 1 July 2020. Mineral compounds, i.e., zinc oxide $(\mathrm{ZnO})$, have traditionally been used to mitigate post-weaning ETEC-F4 diarrhea [5,6]. Some studies have shown that organic acids, functional feedstuffs (blood plasma), feed enzymes, 
prebiotic oligosaccharides, and clay minerals can potentially prevent PWD associated with ETEC $[7,8]$. Due to environmental concerns, there are risks associated with microbial resistance, as well as difficulty of material preparation; thus, it is necessary to find a new effective alternative to antibiotics for the treatment and prevention of bacterial infection diseases, including diarrhea caused by ETEC K88.

It has been confirmed that probiotics are microorganisms that can have beneficial effects on host health, mainly through the production of antibacterial substances, competition with pathogenic bacteria for nutrients and adhesion sites, and enhancing intestinal mucosal barrier integrity to play an immunomodulatory role against diarrhea in weaned piglets [9]. Lactic acid bacteria (LAB) are the most frequently used probiotics, and several studies conducted on newly weaned piglets have noted that LAB can increase the abundance of lactobacilli and bifidobacteria, inhibit colonization of ETEC K88/F4, and improve production of short-chain fatty acid [10]. Patil et al. [11] found Lactobacillus (L.) sobrius may be effective in the reduction of E. coli F4 colonization, and may improve weight gain of infected piglets. Probiotic bacterium L. rhamnosus was effective in ameliorating PWD induced by E. coli K88, modulation of intestinal microflora, and enhancement of intestinal antibody defense [12]. In conclusion, the above research indicate that LAB have a good inhibitory effect on pathogenic bacteria in piglets, especially on intestinal imbalance caused by ETEC K88.

Excellent LAB strains should have characteristics of fast propagation, easy cultivation, strains to maintain a certain activity during production and storage, and a certain tolerance to processing technology in application, and the excellent probiotic LAB still need to be discovered. This study evaluates the probiotic properties of the LAB strains isolated from different sources by determining their inhibitory activities to ETEC K88. After determining physiological and biochemical characteristics, cell surface properties and tolerance to simulated human gastrointestinal (GI) tract and bile test, strains that performed very well were selected identified by $16 \mathrm{~S}$ rRNA gene sequencing and recA gene multiple detection. Strains that performed well in the probiotic test were then evaluated for safety, and the antimicrobial substances and organic acids produced by the fermentation of the strains were determined.

\section{Results}

\subsection{Inhibitory Activities to ETEC K88 of LAB Strains Isolated from Different Sources}

Table 1 showed inhibitory activities to ETEC K88 of LAB strains isolated from different sources. As can be seen, 40 strains (ZA1 to ZA40, Zhengzhou University Agricultural College. Strains were uniformly rebranded as the ZA series for better documentation and preservation) with inhibition zones of at least $18.00 \mathrm{~mm}$ (including that of hole puncher diameter $10.00 \mathrm{~mm}$, and the diameter of all inhibition zones below includes the diameter of the puncher) were selected for further study. Among these strains, ZA2, ZA3, ZA7, ZA8, ZA10, ZA15, ZA18, ZA19, ZA24, ZA28, ZA30, ZA33, and ZA34 had more than $22.00 \mathrm{~mm}$ inhibition zones. The remaining strains were eliminated from the primary screen because of poor inhibition, so they were not listed in the manuscript.

\subsection{Physiological and Biochemical Characteristics of Selected LAB Isolates}

Physiological and biochemical characteristics of selected LAB isolates are shown in Table 2. All strains were able to grow in 3.0 and $6.5(w / v, \%) \mathrm{NaCl}$, and at $\mathrm{pH} 4.0,4.5,5.0,5.5,6.0,8.0$, and 9.0. ZA1, ZA2, ZA3, ZA8, ZA9, ZA10, ZA11, ZA18, ZA28, ZA29, ZA33, ZA34, and ZA40 could grow at $5{ }^{\circ} \mathrm{C}, 50{ }^{\circ} \mathrm{C}$, and $\mathrm{pH} 3.0$, but other strains could not. In addition, ZA6, ZA15, ZA18, ZA26, ZA27, ZA31, ZA32, and ZA33 could produce gas from glucose, while other isolates could not. 
Table 1. Antimicrobial activities to Enterotoxigenic Escherichia coli (ETEC) K88 of representative lactic acid bacteria (LAB) isolates.

\begin{tabular}{|c|c|c|c|c|c|}
\hline Isolates & Antimicrobial Activity & Separation Source & Isolates & Antimicrobial Activity & Separation Source \\
\hline ZA1 & +++ & \multirow{6}{*}{ Weaned piglet feces } & ZA21 & +++ & \multirow{8}{*}{ Rice silage } \\
\hline $\mathrm{ZA} 2$ & ++++ & & ZA22 & +++ & \\
\hline $\mathrm{ZA} 3$ & ++++ & & $\mathrm{ZA} 23$ & +++ & \\
\hline ZA4 & +++ & & $\mathrm{ZA} 24$ & ++++ & \\
\hline ZA5 & +++ & & ZA25 & +++ & \\
\hline ZA6 & +++ & & ZA26 & +++ & \\
\hline ZA7 & ++++ & \multirow{8}{*}{ Feed grass } & ZA27 & +++ & \\
\hline ZA8 & ++++ & & ZA28 & ++++ & \\
\hline ZA9 & +++ & & ZA29 & +++ & \multirow{7}{*}{ Mixture silage } \\
\hline ZA10 & ++++ & & ZA30 & ++++ & \\
\hline ZA11 & +++ & & ZA31 & +++ & \\
\hline ZA12 & +++ & & ZA32 & +++ & \\
\hline ZA13 & +++ & & ZA33 & ++++ & \\
\hline ZA14 & +++ & & ZA34 & ++++ & \\
\hline ZA15 & ++++ & \multirow{3}{*}{ Qula } & ZA35 & +++ & \\
\hline ZA16 & +++ & & ZA36 & +++ & \multirow{5}{*}{ Corn silage } \\
\hline ZA17 & +++ & & ZA37 & +++ & \\
\hline ZA18 & ++++ & \multirow{3}{*}{ Cassava silage } & ZA38 & +++ & \\
\hline ZA19 & ++++ & & ZA39 & $\begin{array}{l}\text { TTT } \\
+++\end{array}$ & \\
\hline $\mathrm{ZA} 20$ & +++ & & ZA40 & +++ & \\
\hline
\end{tabular}

Note: +++ , diameter of inhibition zone: $18.00-22.00 \mathrm{~mm}$; ++++ , more than $22.00 \mathrm{~mm}$; the diameter of inhibition zone including that of hole puncher $(10.00 \mathrm{~mm})$.

Table 2. Physiological and biochemical characteristics of selected LAB isolates.

\begin{tabular}{|c|c|c|c|c|c|c|c|c|c|c|c|c|c|c|c|c|}
\hline \multirow[t]{2}{*}{ Isolates } & \multicolumn{4}{|c|}{$\begin{array}{c}\text { Growth at } \\
\text { Temperature }\left({ }^{\circ} \mathrm{C}\right)\end{array}$} & \multicolumn{2}{|c|}{$\begin{array}{c}\text { Growth in } \\
\mathrm{NaCl}(w / v, \%)\end{array}$} & \multicolumn{9}{|c|}{ Growth at $\mathrm{pH}$} & \multirow{2}{*}{$\begin{array}{c}\text { Fermentation } \\
\text { Type }\end{array}$} \\
\hline & 5 & 10 & 45 & 50 & 3.0 & 6.5 & 3.0 & 3.5 & 4.0 & 4.5 & 5.0 & 5.5 & 6.0 & 8.0 & 9.0 & \\
\hline ZA1 & $\mathrm{w}$ & + & + & + & + & + & $\mathrm{w}$ & + & + & + & + & + & + & + & + & Homo \\
\hline $\mathrm{ZA} 2$ & w & + & + & + & + & + & $\mathrm{w}$ & $\mathrm{w}$ & + & + & + & + & + & + & w & Homo \\
\hline $\mathrm{ZA} 3$ & + & + & + & $\mathrm{w}$ & + & + & + & + & + & + & + & + & + & + & + & Homo \\
\hline ZA4 & + & + & + & $\mathrm{w}$ & + & + & - & - & + & + & + & + & + & + & + & Homo \\
\hline ZA5 & w & $\mathrm{w}$ & + & $\mathrm{w}$ & + & + & - & $\mathrm{w}$ & + & + & + & + & + & + & + & Homo \\
\hline ZA6 & $\mathrm{w}$ & + & + & $\mathrm{w}$ & + & + & w & $\mathrm{w}$ & + & + & + & + & + & + & + & Hetero \\
\hline ZA7 & - & + & w & - & + & + & - & - & + & + & + & + & + & + & + & Homo \\
\hline ZA8 & w & + & + & $\mathrm{w}$ & + & $\mathrm{w}$ & + & + & + & + & + & + & + & + & + & Homo \\
\hline ZA9 & + & + & + & $\mathrm{w}$ & + & + & $\mathrm{w}$ & $\mathrm{w}$ & + & + & + & + & + & + & + & Homo \\
\hline ZA10 & w & + & $\mathrm{w}$ & - & + & + & + & + & + & + & + & + & + & + & + & Homo \\
\hline ZA11 & w & + & + & + & + & + & $\mathrm{w}$ & + & + & + & + & + & + & + & + & Homo \\
\hline ZA12 & + & + & + & + & + & + & - & + & + & + & + & + & + & + & + & Homo \\
\hline ZA13 & w & + & + & + & + & + & $\mathrm{w}$ & + & + & + & + & + & + & + & + & Homo \\
\hline ZA14 & w & + & + & + & + & $\mathrm{w}$ & $\mathrm{w}$ & + & + & + & + & + & + & + & + & Homo \\
\hline ZA15 & - & w & w & - & + & + & $\mathrm{w}$ & + & + & + & + & + & + & + & w & Hetero \\
\hline ZA16 & w & + & + & + & + & + & $\mathrm{w}$ & + & + & + & + & + & + & + & + & Homo \\
\hline ZA17 & - & + & $\mathrm{w}$ & + & + & $\mathrm{w}$ & - & $\mathrm{w}$ & w & + & + & + & + & + & + & Homo \\
\hline ZA18 & w & + & w & $\mathrm{w}$ & + & + & + & $\mathrm{w}$ & + & + & + & + & + & + & + & Hetero \\
\hline ZA19 & w & + & w & - & + & $\mathrm{w}$ & $\mathrm{w}$ & $\mathrm{w}$ & + & + & + & + & + & + & + & Homo \\
\hline ZA20 & $\mathrm{w}$ & + & + & + & + & $\mathrm{w}$ & $\mathrm{w}$ & w & + & + & + & + & + & + & + & Homo \\
\hline ZA21 & w & + & + & $\mathrm{w}$ & + & + & - & w & + & + & + & + & + & + & + & Homo \\
\hline $\mathrm{ZA} 22$ & - & + & + & + & + & w & - & - & w & + & + & + & + & + & + & Homo \\
\hline ZA23 & + & + & w & - & + & $\mathrm{w}$ & - & w & + & + & + & + & + & + & + & Homo \\
\hline ZA24 & + & + & w & w & + & $\mathrm{w}$ & - & w & w & + & + & + & + & + & + & Homo \\
\hline ZA25 & - & + & + & + & + & + & - & $\mathrm{w}$ & + & + & + & + & + & + & + & Homo \\
\hline ZA26 & - & + & w & w & + & + & $\mathrm{w}$ & + & + & + & + & + & + & + & + & Hetero \\
\hline ZA27 & w & + & + & + & + & $\mathrm{w}$ & - & - & $\mathrm{w}$ & + & + & + & + & + & + & Hetero \\
\hline ZA28 & + & + & + & $\mathrm{w}$ & + & + & w & + & + & + & + & + & + & + & + & Homo \\
\hline ZA29 & w & + & + & + & + & $\mathrm{w}$ & w & $\mathrm{w}$ & + & + & + & + & + & + & + & Homo \\
\hline ZA30 & - & + & + & w & + & + & - & - & w & + & + & + & + & + & + & Homo \\
\hline ZA31 & w & + & + & - & + & + & - & + & + & + & + & + & + & + & + & Hetero \\
\hline ZA32 & - & + & + & - & + & + & - & w & + & + & + & + & + & + & + & Hetero \\
\hline ZA33 & + & + & + & + & + & + & + & + & + & + & + & + & + & + & + & Hetero \\
\hline ZA34 & $\mathrm{w}$ & + & + & $\mathrm{w}$ & + & + & + & + & + & + & + & + & + & + & + & Homo \\
\hline ZA35 & w & + & $\mathrm{w}$ & - & + & $\mathrm{w}$ & - & $\mathrm{w}$ & + & + & + & + & + & + & + & Homo \\
\hline ZA36 & - & + & + & $\mathrm{w}$ & + & + & w & w & + & + & + & + & + & + & w & Homo \\
\hline ZA37 & w & + & + & - & + & + & - & - & + & + & + & + & + & + & + & Homo \\
\hline ZA38 & w & + & + & + & + & w & - & w & + & + & + & + & + & + & + & Homo \\
\hline ZA39 & - & + & + & + & + & + & - & $\mathrm{w}$ & + & + & + & + & + & + & + & Homo \\
\hline ZA40 & w & + & + & + & + & $\mathrm{w}$ & w & + & + & + & + & + & + & + & + & Homo \\
\hline
\end{tabular}

Note: + , positive; - , negative; $\mathrm{w}$, weakly positive; homo, homofermentative; hetero, heterofermentative. 


\subsection{S DNA Gene Sequence Analysis and recA Gene Multiple Detection}

Comprehensive inhibitory activity, physiological and biochemical results, ZA2, ZA3, ZA8, ZA10, ZA18, ZA19, ZA28, ZA33, and ZA34 were selected for 16S DNA gene analysis. The 16S DNA sequence analyzing was used for determining the molecular classification of representative LAB strains, and phylogenetic trees that were constructed using nine strains, based on evolutionary distances determined by a neighbor-joining method (shown in Figures 1 and 2). These nine strains were placed in the cluster comprised of the genera Lactobacillus, Weissella (W.) and Enterococcus (E.).

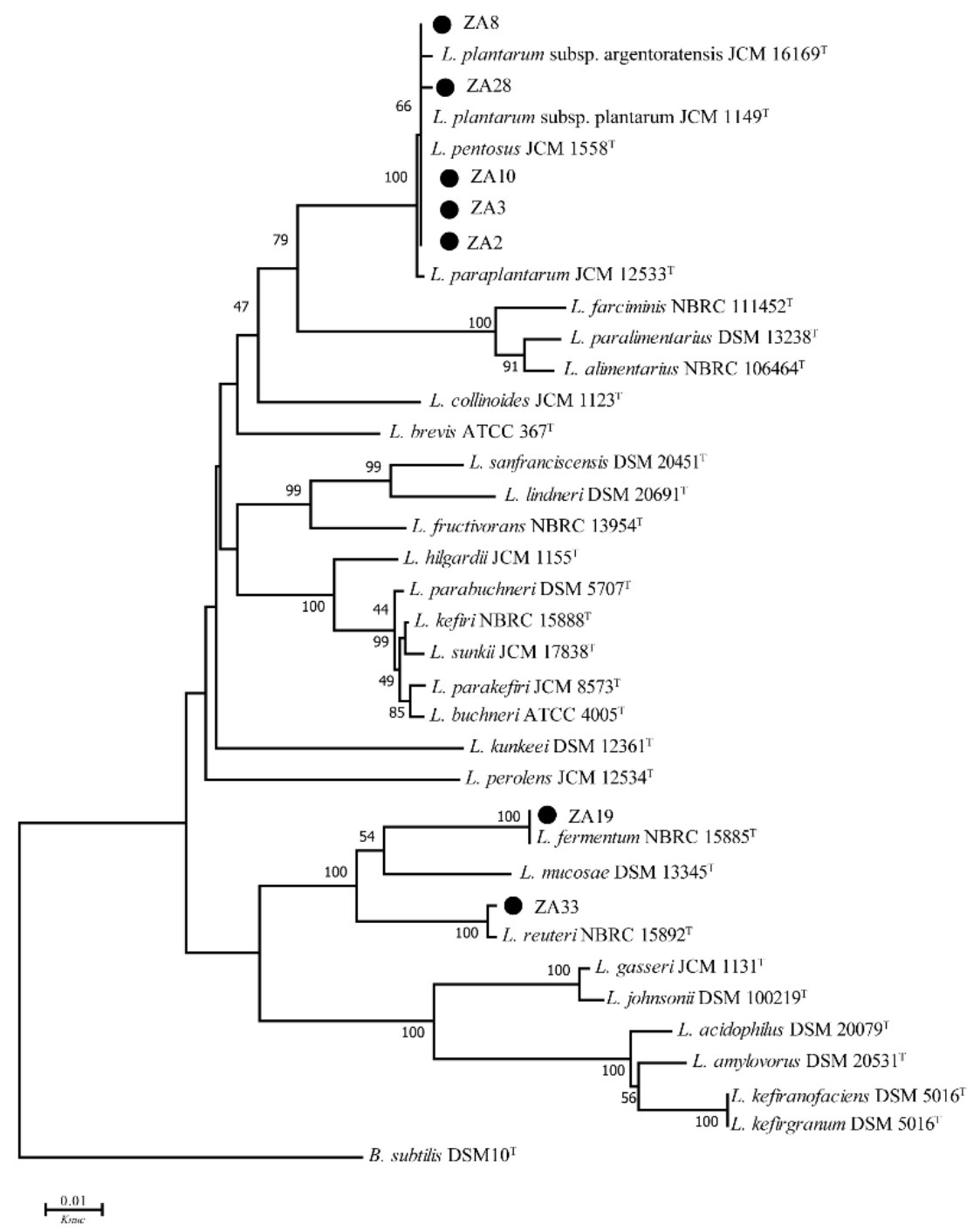

Figure 1. Phylogenetic tree of selected Lactobacillus strains. Bootstrap values for 1000 replicates are shown at the nodes of the tree, and Bacillus subtilis is used as an outgroup. The bar indicates $1 \%$ sequence divergence. $L .=$ Lactobacillus, $B .=$ Bacillus, $K n u c=$ nucleotide substitution rate.

As shown in Figure 1, strains ZA2, ZA3, ZA8, ZA10, and ZA28 placed in the L. plantarum cluster, could not be distinguished by $16 \mathrm{~S}$ DNA sequencing. The recA gene PCR amplification products of these five strains, and the type strains in the L. plantarum cluster, including L. casei, L. paraplantarum, L. pentosus, L. plantarum subsp. plantarum, and L. plantarum subsp. argentoratensis, were shown in Figure 3. As can be seen, these five strains, and L. plantarum subsp. plantarum JCM $1149^{\mathrm{T}}$, had 318 bp products, while the negative control $L$. casei did not produce any amplicons. Thus, strains ZA2, ZA3, ZA8, ZA10, and ZA28 could be assigned to L. plantarum subsp. plantarum, as ZA19 and ZA33 were also placed in the cluster of the genus Lactobacillus, and they could be identified as L. fermentum 
and $L$. reuteri-both supported by $100 \%$ bootstrap values, respectively, and both between $99 \%$ shared similarity in their 16S DNA.

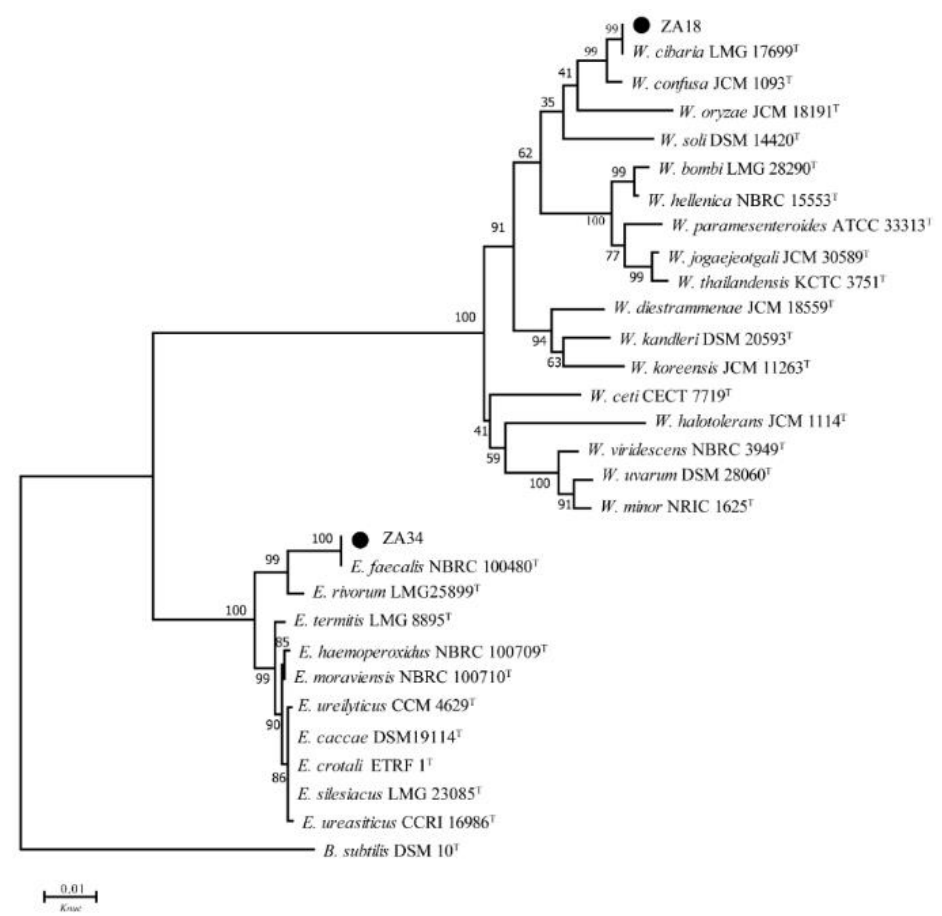

Figure 2. Phylogenetic tree of ZA18 and ZA34. Bootstrap values for 1000 replicates are shown at the nodes of the tree and Bacillus subtilis is used as an outgroup. The bar indicates $1 \%$ sequence divergence. W. $=$ Weissella, E. = Enterococcus, $B .=$ Bacillus, Knuc $=$ nucleotide substitution rate.

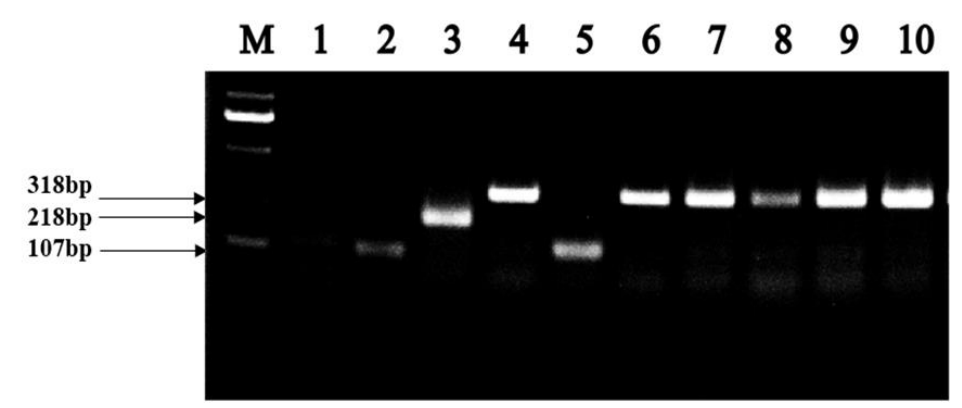

Figure 3. Amplification products obtained from the $r e c A$ multiplex assay. Lane M contained a $2000 \mathrm{bp}$ PLUS DNA ladder. Lanes 1, 2, 3, 4 and 5, PCR amplification products from L. casei JCM $16167^{\mathrm{T}}$ (negative control), L. paraplantarum JCM $12533^{\mathrm{T}}$, L. pentosus JCM $1558^{\mathrm{T}}$, L. plantarum subsp. plantarum JCM $1149^{\mathrm{T}}$, and L. plantarum subsp. argentoratensis JCM $16169^{\mathrm{T}}$, respectively; lane 6, 7, 8, 9, and 10, PCR amplification product from ZA3, ZA2, ZA28, ZA8 and ZA10.

In Figure 2, strain ZA18 was placed in the Weissella cluster, with the species W. cibaria LMG $17699^{\mathrm{T}}$ being the most closely related species, which was supported by $99 \%$ bootstrap analysis in the phylogenetic tree and more than 99\% similarity in the 16S rRNA gene sequence. Therefore, strain ZA18 belonged to W. cibaria. Strain ZA34, placed in the cluster of the genus Enterococcus in the phylogenetic tree, was clearly identified as Enterococcus faecalis, since it formed a very well-defined cluster (100\% bootstrap) with E. faecalis.

\subsection{Cell Surface Properties of Selected LAB Isolates}

The hydrophobicity and auto-aggregation ability of nine selected LAB isolates are shown in Figure 4. Figure $4 \mathrm{a}$ exhibited strains had significant differences in hydrophobicity, among these 
nine strains, ZA3 had the highest hydrophobicity at $59.7 \%$, and the lowest was ZA33, only $9.9 \%$. The auto-aggregation ability of isolates was presented in Figure $4 \mathrm{~b}$; all tested isolates showed lower auto-aggregation ability at $2 \mathrm{~h}$, while at $8 \mathrm{~h}$ increased significantly. ZA3 also showed the highest auto-aggregation at $78.95 \%$ in comparison to other LAB isolates tested. Thus, ZA2, ZA3, ZA8, ZA10, ZA28, and ZA34 were used for further testing.
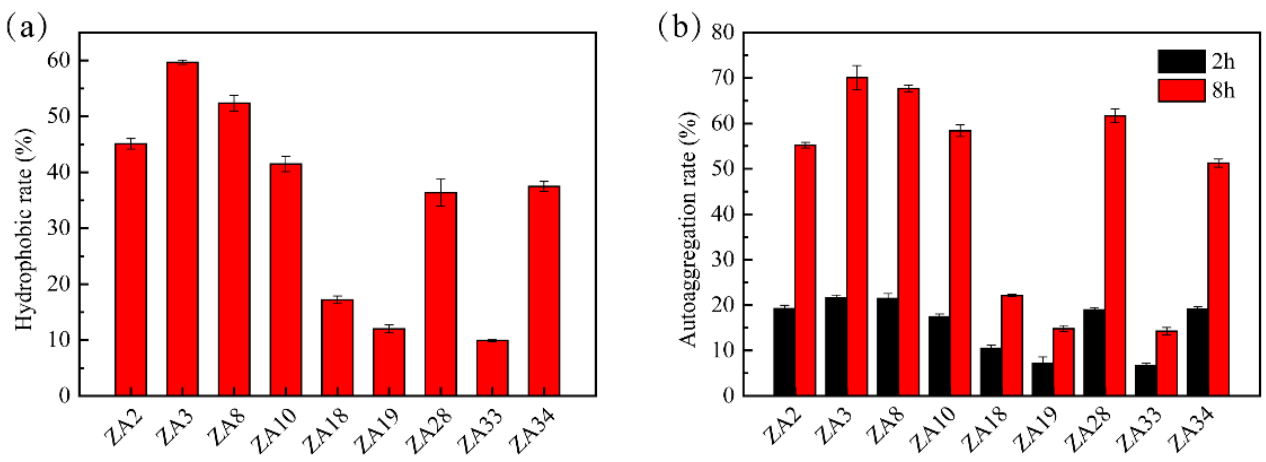

Figure 4. Cell surface hydrophobicity and auto-aggregation ability of lactic acid bacterial isolates.

(a) hydrophobicity of selected LAB isolates; (b) auto-aggregation ability of selected LAB isolates.

\subsection{Acid Production Capacity and Growth Curve of Selected LAB Isolates}

Acid production capacity and growth curve of six selected LAB isolates cultivated at 30 and $39^{\circ} \mathrm{C}$ are shown in Figure 5. There was no significant difference in the acid-producing ability of ZA2, ZA3, ZA8, ZA10, ZA28, and ZA34 within $48 \mathrm{~h}$, among which ZA3 had the lowest $\mathrm{pH}$ at 3.0 after $48 \mathrm{~h}$ fermentation (Figure $5 \mathrm{a}, \mathrm{b}$ ), moreover, strains showed stronger acid production ability under cultivated at $39{ }^{\circ} \mathrm{C}$ compared with $30^{\circ} \mathrm{C}$. Figure $5 \mathrm{c}$ and d show the growth curve of these six isolates in $24 \mathrm{~h}$ cultivate at 30 and $39^{\circ} \mathrm{C}$, respectively, and from which one could see that the growth adaptation period of all six strains was from 0 to $2 \mathrm{~h}$, and the logarithmic growth period was from 2 to $16 \mathrm{~h}$.

(a)
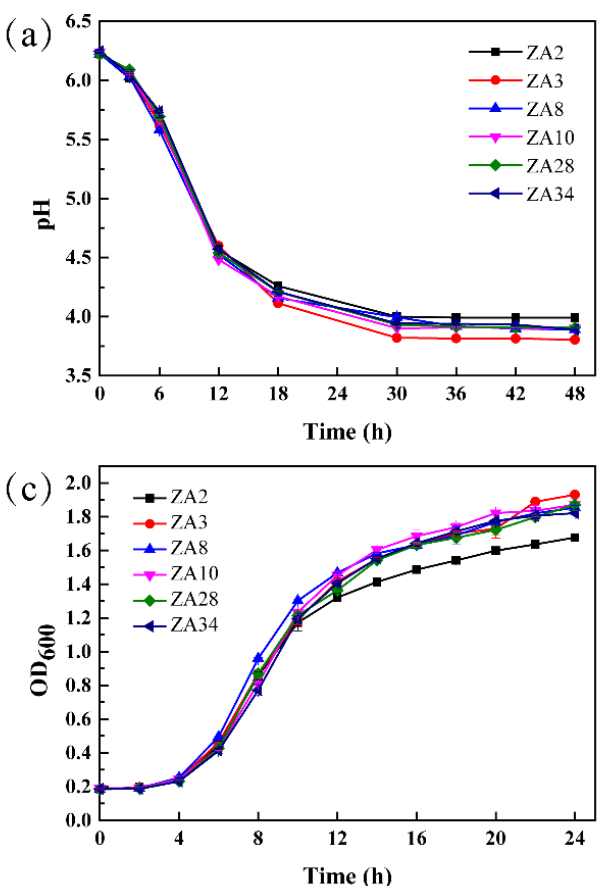
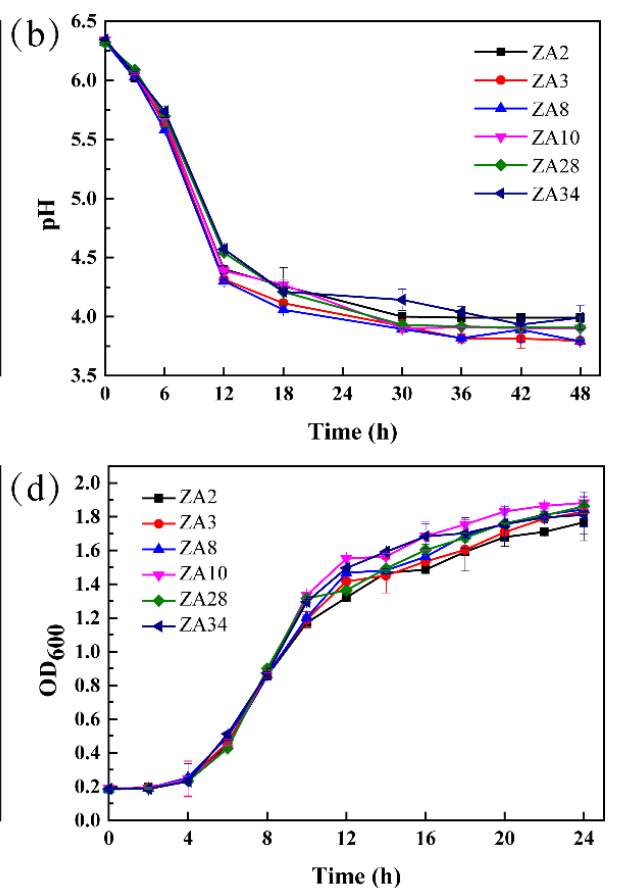

Figure 5. Acid production capacity and growth curve of six lactic acid bacterial isolates. $(\mathbf{a}, \mathbf{b})$, acid production curve of six $\mathrm{LAB}$ isolates cultivated at 30 and $39^{\circ} \mathrm{C}$, respectively; (c,d), growth curve of six LAB isolates cultivated at 30 and $39^{\circ} \mathrm{C}$, respectively. 


\section{6. $p H 2.5$ and Bile Salt Resistance of Selected LAB Isolates.}

Figure $6 \mathrm{a}$ and b separately showed $\mathrm{pH} 2.5$ and $\mathrm{pH} 6.2$ resistance of six selected LAB isolates cultivated at 30 and $39^{\circ} \mathrm{C}$. Optical density (OD) values of all six test LAB isolates were significantly different after being treated at $\mathrm{pH} 2.5$ for 2, 4, and $6 \mathrm{~h}$. All isolates had certain vigor after $2 \mathrm{~h}$ incubation at $30^{\circ} \mathrm{C}$, of which the highest was ZA8 with 1.456 . After $4 \mathrm{~h}$ incubation at $30^{\circ} \mathrm{C}$, only ZA3 and ZA8 still had certain vigor, and ZA3 with $1.200 \mathrm{OD}$ value. For $39^{\circ} \mathrm{C}$, all isolates had certain vigor after $2 \mathrm{~h}$ incubation, of which ZA3, ZA8, ZA10, and ZA34 with the OD value was 1.478, 1.566, 1.585, and 1.376, respectively. After $4 \mathrm{~h}$ incubation, ZA3 still had $1.322 \mathrm{OD}$ value. As for $6 \mathrm{~h}$ incubation at 30 and $39{ }^{\circ} \mathrm{C}$, no isolate had viability.
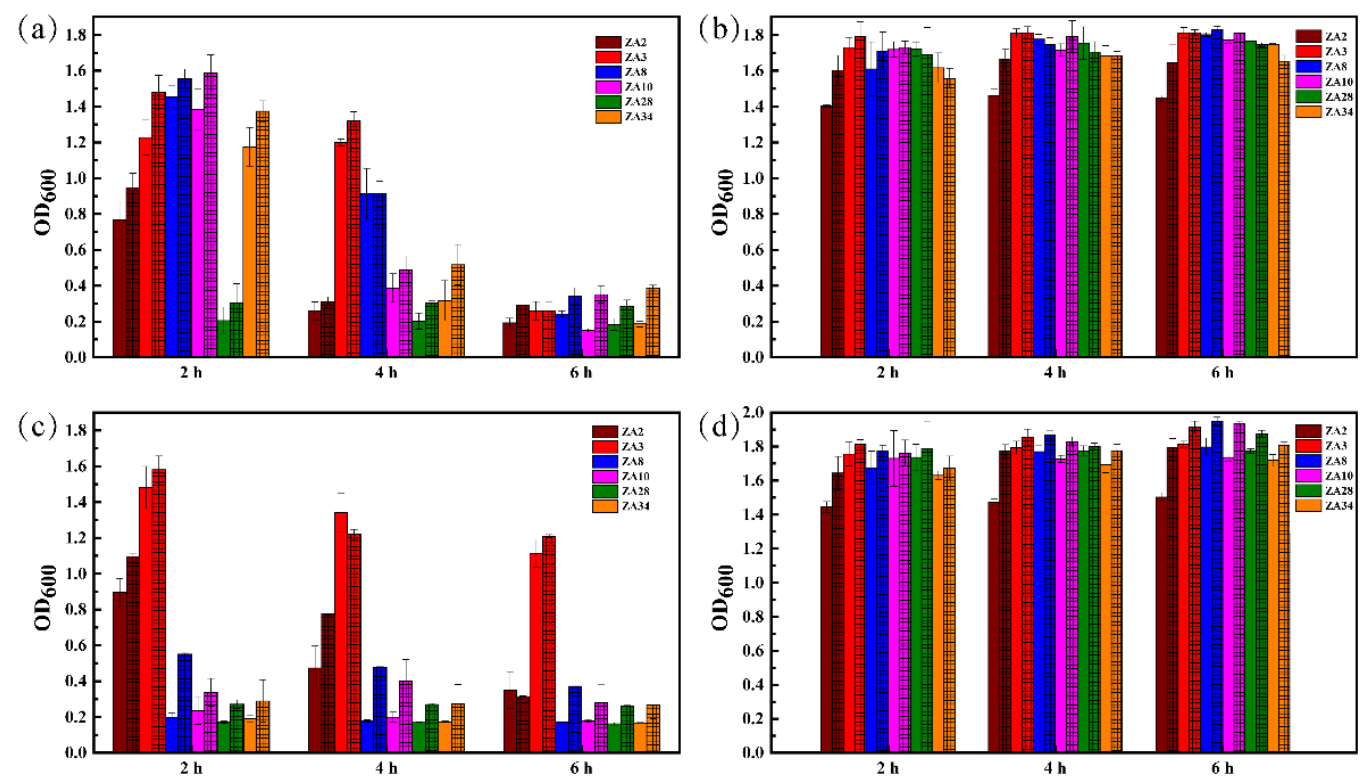

Figure 6. Biomass of six LAB isolates grown for $20 \mathrm{~h}$ after treatment in different acidic or bile salt environments with different times; (a) $\mathrm{pH} 2.5$ treatment and cultivate at 30 and $39{ }^{\circ} \mathrm{C},(\mathbf{b}) \mathrm{pH} 6.2$ treatment and cultivate at 30 and $39^{\circ} \mathrm{C}$, (c) $0.5 \%$ bile salt treatment and cultivate at 30 and $39{ }^{\circ} \mathrm{C}$, and (d) $0 \%$ bile salt treatment and cultivate at 30 and $39{ }^{\circ} \mathrm{C}$.

From Figure $6 c, d$, all six LAB isolates tested exhibited different viability after exposure to $0.5 \%$ bile salt and control for 2, 4, and $6 \mathrm{~h}$. At $30^{\circ} \mathrm{C}$, only ZA2 and ZA3 had vitality with OD 0.896, and 1.481 after $2 \mathrm{~h}$ incubation, respectively, while other strains had no activity. After $4 \mathrm{~h}$ incubation, all strains were almost inactive (OD value of ZA2 was 0.474 ) except ZA3, which still had 1.341 OD value; for $6 \mathrm{~h}$, the OD value of ZA3 was also 1.115. Regarding $39^{\circ} \mathrm{C}$, only ZA2 and ZA3 had vitality with OD 1.096 and 1.583 after $2 \mathrm{~h}$ incubation, while other strains had no activity; after $4 \mathrm{~h}$ incubation, only ZA3 had 1.219 OD value; after $6 \mathrm{~h}$ treatment, the OD value of ZA3 was also 1.210.

Based on the excellent pH 2.5 and bile salt tolerance of ZA3 in selected isolates, only ZA3 was selected for subsequent experiments.

\subsection{Survival of ZA3 after Simulation Gastrointestinal (GI) Exposure}

Figure 7 illustrates the viable count (log colony forming units, CFU/mL) of the strain ZA3 during GI exposure. The population of ZA3 before in simulated gastric fluid (SGF) was $8.72 \log$ CFU/mL, while after $3 \mathrm{~h}$ incubation in SGF, the population of ZA3 was $8.20 \log \mathrm{CFU} / \mathrm{mL}$, and the survival ratio was $94.03 \%$. As for simulated intestinal fluid (SIF), an initial population of ZA3 was $8.01 \log$ CFU/mL, the population reduced to $7.92 \log \mathrm{CFU} / \mathrm{mL}$ after $4 \mathrm{~h}$ treatment, which was, to say, the survival ratio of ZA3 after the SIF phase was $98.88 \%$. 


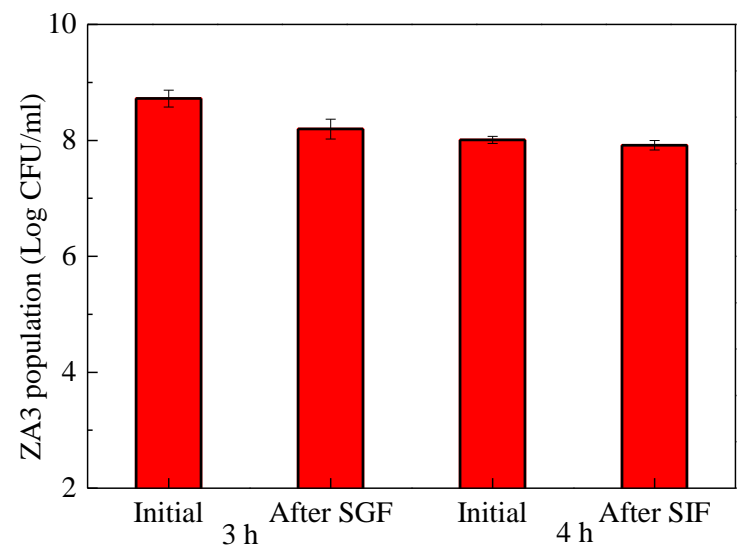

Figure 7. Surviving of ZA3 during a simulated gastrointestinal (GI) exposure.

\subsection{Safety Evaluation of ZA3}

\subsubsection{Safety Properties of ZA3}

The results of virulence factor genes, biogenic amine genes, and antibiotic resistance gene amplification of ZA3 are shown in Table 3. PCR results revealed that ZA3 did not harbor any virulence genes, such as collagen genes associated with adhesin (ace), gelatinase gene (gelE), and the cytolysin gene (cylA), biogenic amine genes, such as histidine decarboxylase (hdc), tyrosine decarboxylase (tdc), and ornithine decarboxylase (odc), and antibiotic resistance genes, such as the vancomycin resistance gene (vanA) and the tetracycline resistance gene (tetM).

Table 3. Detection of virulence factor gene, biogenic amine production gene, and antibiotic resistance gene in ZA3.

\begin{tabular}{ccccccccc}
\hline \multirow{2}{*}{ Isolate } & \multicolumn{2}{c}{ Virulence Factors Genes } & \multicolumn{3}{c}{ Biogenic Amines Genes } & \multicolumn{2}{c}{ Antibiotic Resistance Genes } \\
\cline { 2 - 9 } & ace & gelE & cylA & hdc & tdc & odc & vanA & tetM \\
\hline ZA3 & - & - & - & - & - & - & - & - \\
\hline
\end{tabular}

\subsubsection{Assessment of Antibiotic Susceptibility}

Table 4 shows antibiotic susceptibility of isolate L. plantarum subsp. plantarum ZA3, and the cut-off value for antibiotic resistance of LAB are also shown, which demonstrated the strain was sensitive to carbenicillin, ampicillin, erythromycin, chloramphenicol and amikacin, the minimum inhibitory concentration (MIC) were $0.5,1,1,8$ and $20 \mu \mathrm{g} / \mathrm{mL}$, respectively, and resistant to cefamezin, gentamicin, norfloxacin, clindamycin and penicillin, the MIC were 10, 64, >512, 8 and $64 \mu \mathrm{g} / \mathrm{mL}$, respectively.

Table 4. Antibiotic susceptibility, MIC and cut-off value of isolate ZA3.

\begin{tabular}{ccccccccccc}
\hline Item & CB & CZ & AM & GM & NOR & CC & P & E & C & AK \\
\hline MIC $(\mu \mathrm{g} / \mathrm{mL})$ & 0.5 & 10 & 1 & 64 & $>512$ & 8 & 64 & 1 & 8 & 20 \\
cut-off value $(\mu \mathrm{g} / \mathrm{mL})$ & 2 & 2 & 2 & 16 & 4 & 2 & 2 & 8 & 8 & 64 \\
ZA3 & $\mathrm{S}$ & $\mathrm{R}$ & $\mathrm{S}$ & $\mathrm{R}$ & $\mathrm{R}$ & $\mathrm{R}$ & $\mathrm{R}$ & $\mathrm{S}$ & $\mathrm{S}$ & $\mathrm{S}$ \\
\hline
\end{tabular}

Notes: S: Susceptible; I: Intermediate resistant; R: Resistant. Refer to the latest Clinical and Laboratory Standards Institute (CLSI) standard. CB: carbenicillin; CZ: cefamezin; AM: ampicillin; GM: gentamicin; NOR: norfloxacin; CC: clindamycin; P: penicillin; E: erythromycin; C: chloramphenicol; AK: amikacin. Cut-off value cited from EFSA.

\subsubsection{Hemolytic Activity of ZA3}

As shown in Figure 8, compared with positive control, Staphylococcus aureus ATCC $6538^{\mathrm{T}}$, having blood hemolysis activity in Figure 8b, ZA3 in Figure 8a showed no hemolytic activity. 

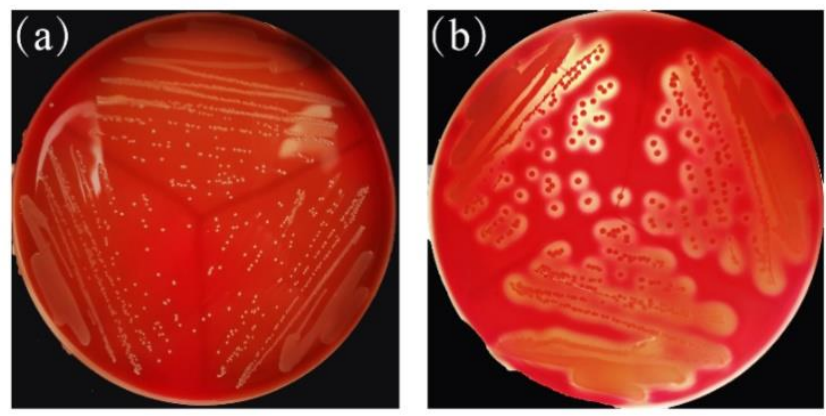

Figure 8. Hemolytic activity of ZA3; (a) ZA3, (b) positive control: Staphylococcus aureus ATCC $6538^{\mathrm{T}}$.

2.8.4. Toxicity Test of the ZA3 Strain against intestinal epithelial (IPEC-J2) Cells

Cell Counting Kit-8 (CCK-8) results are shown in Figure 9. When treated with 1 multiplicity of infection (MOI ZA3), the cells showed normal activity at all time periods, which was not significant compared to the control $(p>0.05)$. As for 2 MOI ZA3, after $2 \mathrm{~h}$ reaction, cell viability was slightly reduced, and it did not damage cells or affect cell viability after $4 \mathrm{~h}$ reaction. Regarding being treated with $3 \mathrm{MOI} Z \mathrm{ZA} 3$, cells were severely damaged, and the survival rate was significantly reduced compared with control cells $(p<0.05)$. After $4 \mathrm{~h}$ reaction, the cell survival rate was significantly reduced $(p<0.01)$. Moreover, cell survival rate was significantly reduced, and cells were severely damaged $(p<0.01)$ after being treated with 2 and 3 MOI for 12 and $24 \mathrm{~h}$.

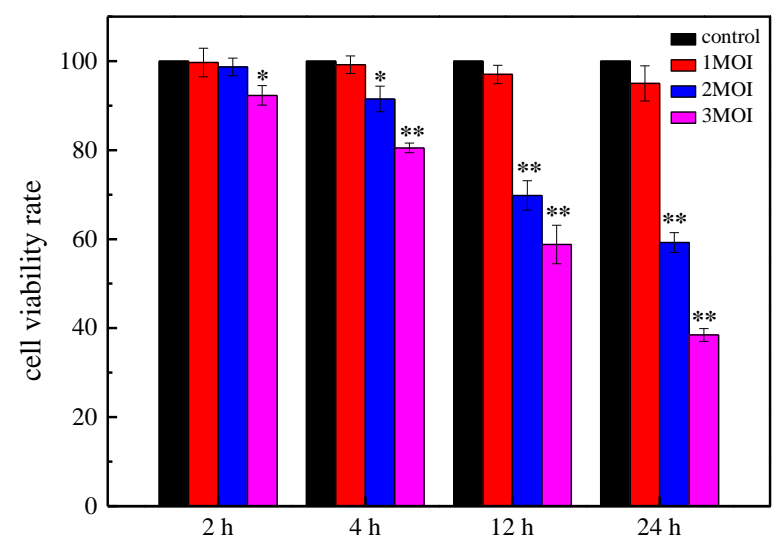

Figure 9. Cell viability rates of intestinal epithelial (IPEC-J2) after different time incubation with different concentrations of ZA3. The asterisk denotes a significant difference compared with control $\left({ }^{*} p<0.05,{ }^{* *} p<0.01\right)$.

\subsection{Antimicrobial Spectrum Test of ZA3}

Results of the agar well diffusion in Table 5 displayed that ZA3 demonstrated powerful antimicrobial activity against all selected microorganisms tested in this work. As can be seen, inhibition zone diameters of more than $22.00 \mathrm{~mm}$ were Pseudomonas aeruginosa ATCC $15692^{\mathrm{T}}$ and Listeria monocytogenes ATCC $51719^{\mathrm{T}}$, as for Escherichia coli ATCC $11775^{\mathrm{T}}$, Staphylococcus aureus ATCC $6538^{\mathrm{T}}$, Bacillus subtilis ATCC $19217^{\mathrm{T}}$, Micrococcus luteus ATCC $4698^{\mathrm{T}}$, and Salmonella enterica ATCC $43971^{\mathrm{T}}$, inhibition zone diameters were all above $18.00 \mathrm{~mm}$. 
Table 5. Antibacterial spectrum of ZA3.

\begin{tabular}{cccccccc}
\hline \multirow{2}{*}{ Isolate } & \multicolumn{7}{c}{ Indicator Bacteria } \\
\cline { 2 - 8 } & E. coli & P. aeruginosa & S. aureus & B. subtilis & L. monocytogenes & M. luteus & S. enterica \\
\hline ZA3 & +++ & ++++ & +++ & +++ & ++++ & +++ & +++ \\
\hline
\end{tabular}

Notes: 1. +++, diameter of inhibition zone: $18.00-22.00 \mathrm{~mm}$; ++++, more than $22.00 \mathrm{~mm}$; the diameter of inhibition zone including that of hole puncher $(10.00 \mathrm{~mm})$; 2. E. coli: Escherichia coli ATCC $11775^{\mathrm{T}}$; P. aeruginosa: Pseudomonas aeruginosa ATCC $15692^{\mathrm{T}}$; S. aureus: Staphylococcus aureus ATCC $6538^{\mathrm{T}}$; B. subtilis: Bacillus subtilis ATCC $19217^{\mathrm{T}}$; $L$. monocytogenes: Listeria monocytogenes ATCC $51719^{\mathrm{T}}$; M. luteus: Micrococcus luteus ATCC $4698^{\mathrm{T}}$; S. enterica: Salmonella enterica ATCC $43971^{\mathrm{T}}$.

\subsection{Carbohydrate Utilization Patterns of ZA3}

Carbohydrate utilization patterns of ZA3 are shown in Table 6, and results indicate that ZA3 could use galactose, D-glucose, D-fructose, mannose, L-sorbose, rhamnose, mannitol, sorbitol, maltose, lactose, melibiose, saccharose, trehalose, gluconate, $\mathrm{N}$-acetyl glucosamine, and amygdalin as carbon sources, and ribose could be weakly used. Other than that, the remaining carbon sources, such as glycerol, D-arabinose, L-arabinose, D-xylose, dulcitol, inositol, salicin, melezitose, D-raffinose, starch, xylitol, and L-arabitol were completely unavailable.

Table 6. Carbohydrate utilization patterns of ZA3.

\begin{tabular}{cccc}
\hline Substrate & ZA3 & Substrate & ZA3 \\
\hline Glycerol & - & Salicin & - \\
D-Arabinose & - & Cellobiose & - \\
L-Arabinose & - & Maltose & + \\
Ribose & $\mathrm{w}$ & Lactose & + \\
D-Xylose & - & Melibiose & + \\
Galactose & + & Saccharose & + \\
D-Glucose & + & Trehalose & + \\
D-Fructose & + & Melezitose & - \\
Mannose & + & D-Raffinose & - \\
L-Sorbose & + & Starch & - \\
Rhamnose & + & Xylitol & - \\
Dulcitol & - & L-Arabitol & + \\
Inositol & - & Gluconate & + \\
Mannitol & + & N-acetyl glucosamine & + \\
Sorbitol & + & Amygdalin & - \\
Glycerol & - & Salicin & - \\
D-Arabinose & - & Cellobiose & + \\
L-Arabinose & - & Maltose & + \\
Ribose & $\mathrm{w}$ & Lactose & \\
\hline
\end{tabular}

Note: +, positive; -, negative; $\mathrm{w}$, weakly positive.

\subsection{Identification of the Antimicrobial Substance Produced by ZA3}

Effects of $\mathrm{pH}$, enzymes, and hydrogen peroxide on the antimicrobial activity of ZA3 against ETEC K88 are shown in Table 7. The inhibition zone diameter of fermentation liquid and supernatant of ZA3 were both above $18.00 \mathrm{~mm}$. The results summarized that the hydrogen peroxide did not affect antimicrobial activity of ZA3 based on the inhibition zone diameter, and were still above $18.00 \mathrm{~mm}$ after being treated by hydrogen peroxide. At the same time, after being treated with pepsinum and tryptase, the inhibition zone diameter was still above $18.00 \mathrm{~mm}$. As for proteinase $K$, the diameter was also between 14.00-18.00 mm. However, when tested the effects of different $\mathrm{pH}$, the antimicrobial activity of ZA3 decreased with increasing $\mathrm{pH}$, which was not affected by $\mathrm{pH} 3.0$ and 4.0, obviously, but slightly decreased at $\mathrm{pH} 4.5$. A complete loss of activity was observed at $\mathrm{pH}$ values ranging from 5.5 to 10.0. Therefore, antibacterial substances produced by ZA3 may be acid. 
Table 7. Antimicrobial activity of ZA3 to ETEC K88 after different treatment.

\begin{tabular}{cc}
\hline Treatment & Antimicrobial Activity \\
\hline ZA3 & +++ \\
fermentation liquid & +++ \\
supernatant & +++ \\
hydrogen peroxide & ++ \\
proteinase K & +++ \\
pepsinum & +++ \\
tryptase & \\
pH & +++ \\
3.0 & +++ \\
4.0 & ++ \\
4.5 & + \\
5.0 & - \\
5.5 & - \\
6.0 & - \\
6.5 & - \\
7.0 & - \\
10.0 & + \\
\hline
\end{tabular}

Note: +, diameter of inhibition zone: $10.00-14.00 \mathrm{~mm} ;++, 14.0-18.00 \mathrm{~mm} ;+++, 18.0-22.00 \mathrm{~mm} ;-$, no inhibition zone was detected; the diameter of inhibition zone including that of hole puncher $(10.00 \mathrm{~mm})$.

\subsection{Organic Acid Produced by Fermentation of $Z A 3$}

Liquid chromatography was used to analyze the acid production of ZA3 after $24 \mathrm{~h}$ fermentation. As shown in Figure 10, four kinds of organic acid were mainly detected in the fermentation broth: citric acid, succinic acid, lactic acid, and acetic acid. The content was $0.822,0.576,2.545$, and $1.729 \mathrm{mg} / \mathrm{mL}$, respectively.

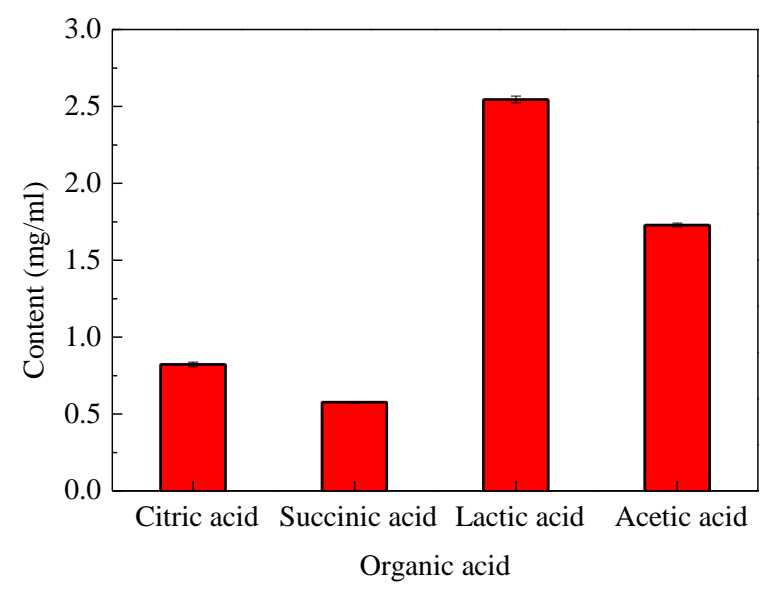

Figure 10. The organic acid produced by fermentation of ZA3.

\section{Discussion}

In this study, to obtain functional probiotic bacteria that inhibit ETEC K88, more than 1100 LAB from different sources were tested and 40 isolates with an inhibition zone diameter of $18.00 \mathrm{~cm}$ or more were selected. ETEC is the main pathogenic bacterium that causes diarrhea in humans and young animals. As one of the indispensable floras with important physiological functions in human and animal bodies, LAB has the incomparable host bacteria advantages of other receptor strains. Sirichokchatchawan et al. [13] reported the strain L. plantarum showed antagonistic activity against E. coli; a $6.0-9.00 \mathrm{~mm}$ inhibitor zone diameter was considered to be weak inhibition and marked as +. Moreover, 10.0-13.00 mm (intermediate inhibition) was marked as,$++ 14.0-16.00 \mathrm{~mm}$ (strong inhibition) was marked as +++ , and more than $17.00 \mathrm{~mm}$ (very strong) was marked as ++++ 
by the agar well diffusion method (including that of the hole puncher, $6.00 \mathrm{~mm}$ ). While in this study, 13 isolates had more than $22.00 \mathrm{~mm}$ inhibition zones by using the same test method, the only difference being that the diameter of the hole puncher used was $10.00 \mathrm{~mm}$.

One of the most important criteria for selecting LAB with probiotic properties is the ability to tolerate the environment of the gastrointestinal tract, with the $\mathrm{pH}$ of pig gastric juices being as low as 2.0, and bile with a pH of about 8.0. Dushku et al. [14] isolated and identified 40 LAB strains from the gastrointestinal tract of local snails, which were artificially simulated to survive the gastrointestinal tract of only two strains. Rao et al. [15] screened L. plantarum AT4 for low $\mathrm{pH}$ and up to $0.5 \%$ bile salts. This study found 40 selected strains with excellent inhibition abilities; 13 homo-fermentative isolates could grow at 5 to $50{ }^{\circ} \mathrm{C}$, and $\mathrm{pH} 3.0-10.0$, and ferment glucose without producing gas. Considering that the temperature of weaned piglets is usually around 38.5 to $40{ }^{\circ} \mathrm{C}$, the study examined acid production capacity, growth situation, low $\mathrm{pH}$, and bile salt tolerance of selected LAB strains at $39{ }^{\circ} \mathrm{C}$ in addition to the optimal $30^{\circ} \mathrm{C}$ conditions. As can be seen, all six selected strains showed stronger acid production ability under $39{ }^{\circ} \mathrm{C}$, compared with $30{ }^{\circ} \mathrm{C}$, and the growth of strains were not affected at $39{ }^{\circ} \mathrm{C}$. Additionally, there was no significant difference between $\mathrm{pH} 2.5$ and $0.5 \%$ bile salt resistance of the six selected $\mathrm{LAB}$ strains cultured at 30 and $39^{\circ} \mathrm{C}$. These results further suggest that the selected strains have potential for application as animal intestinal probiotics. Relative to heterofermentative LAB, producing a mix of lactic acid and acetic acid, homofermentative LAB promotes rapid fermentation, primarily producing lactic acid and rapidly reducing the $\mathrm{pH}$, preventing the growth of other undesirable spoilage organisms, which indicated that these strains satisfied the demands for growth in relatively extreme environments. In a word, the excellent physiological and biochemical characteristics provide tremendous potential for selected strains in practical applications [16].

Species identification is the basis for conducting scientific experiments, and the identification of the genus provides an indirect understanding of the bacteria's habits, metabolism, and pathogenic patterns. In this study, phylogenetic trees were constructed based on the evolutionary distances of their 16S DNA sequences using the neighbor-joining method to identify selected LAB isolates at the species level. Selected strains were placed in clusters comprised of genera Lactobacillus, Weissella, and Enterococcus, since strains ZA2, ZA3, ZA8, ZA10, and ZA28 were clearly assigned to the genus Lactobacillus, and grouped in the L. plantarum cluster on the phylogenetic tree with type strains L. casei JCM $16167^{\mathrm{T}}$, L. paraplantarum JCM $12533^{\mathrm{T}}$, L. pentosus JCM $1558^{\mathrm{T}}$, L. plantarum subsp. plantarum JCM $1149^{\mathrm{T}}$, and L. plantarum subsp. argentoratensis JCM $16169^{\mathrm{T}}$, which could not be separated by $16 \mathrm{~S}$ rDNA [17]. By means of recA gene, PCR amplification products, these five strains and L. plantarum subsp. plantarum JCM $1149^{\mathrm{T}}$ had 318 bp products, while the negative control L. casei and the other three type strains did not produce any amplicons; thus, ZA2, ZA3, ZA8, ZA10, and ZA28 strains could also be accurately identified as L. plantarum subsp. plantarum.

Adherence is a prerequisite for strains to colonize the gut and increase their viability. Only if the strain is able to adhere and colonize the intestinal tract can it promote immune regulation and stimulate the intestinal barrier and metabolism function [18]. Adherence mainly includes cell surface hydrophobicity, self-aggregation, and co-aggregation to indicator bacteria, and its effect on intestinal cells. It has been shown that high hydrophobicity and auto-aggregation ability could promote the colonization of beneficial microorganisms in the gastrointestinal tracts of human hosts [19]. In this study, ZA3 from weaned pig feces showed the highest hydrophobic activity (59.70\%) and auto-aggregation ability $(78.95 \%)$ in comparison to other LAB isolates tested, and the results are consistent with previous studies that the higher the surface hydrophobicity of these isolates, the stronger the self-aggregation ability [20].

As a functional LAB, it should overcome several challenging environmental conditions, such as extremely high or low $\mathrm{pH}$, salt, and bile, all are the most common factors [21]. In the present study, it was found that ZA3 still had certain vigor after $4 \mathrm{~h}$ incubation in different acidic or bile salt environments, and exhibited $94.03 \%$ survival rate after $3 \mathrm{~h}$ in simulated gastric juice. The results obtained by Joghataei et al. [22] displayed that L. fermentum FH19 exhibited the highest survival rate (96\%) after $3 \mathrm{~h}$ in SGF. 
Comparatively speaking, ZA3 had $98.88 \%$ survival ratio after the SIF phase in this study, indicating that it has a significant effect on SGF and SIF tolerance. Lee et al. [23] reported L. plantarum C182 possessed a significant level of resistance against $0.3 \%$ bile salts, while ZA 3 had vitality with OD value 1.115 after exposure to $0.5 \%$ bile salt for $6 \mathrm{~h}$.

Safety is also one of the basic criteria for screening strains, LAB, especially Lactobacillus, are usually considered safe. However, it has recently been discovered that Lactobacillus and Bifidobacterium are frequently isolated from diseased tissues, such as endocarditis and sepsis $[24,25]$. Therefore, it is necessary to re-evaluate their safety. In addition, the safety evaluation of probiotics has become more important with the isolation and application of new probiotics and the emergence of genetically modified probiotics. As isolated strains Lactobacillus MMP4 wanted to be used in the dairy industry, Choudhary et al. [26] used PCR to investigate whether strain MMP4 was an antibiotic resistant gene, and had safety parameters, such as gelatinase and hemolytic activity. In this study, all tested strains were PCR-negative for all the virulence factors, including virulence factor genes, biogenic amines genes, and antibiotic resistances genes, and antibiotic susceptibility and hemolytic activity, which are at risk for genetic transfer. The MIC of ZA3 to carbenicillin, cefamezin, ampicillin, clindamycin, erythromycin, and chloramphenicol were $0.5,10,1,8,1$, and $8 \mu \mathrm{g} / \mathrm{mL}$, which was consistent with the study by Nawaz et al. [27], respectively. CCK-8 assay for the cytotoxicity of ZA3 on IPJC-2 cells showed that the strain was not cytotoxic. In addition, there was absence of hemolysis on blood agar, indicating that $\mathrm{ZA} 3$ could have potential as a safety probiotic candidate.

The ultimate goal of screening LAB is application, and the ability to utilize a wider variety of carbon sources, indicating that the strain ZA3 was easy to culture and has greater viability, which is of greater value in research and production.

There is a wide variety of antibiotics, and antibiotic inhibition spectrum varies by antibiotic type, when using probiotics instead of antibiotics, which probiotics should be used instead of antibiotics? Is it a complete replacement or a partial replacement? It is difficult for feed and breeding companies to make these decisions. Moreover, probiotics typically exhibit narrow killing spectrum, inhibiting only those bacteria that are closely related to them. Therefore, it is very important to screen strains with a wide antimicrobial spectrum and define the range of antimicrobial spectrum of the strains. In this study, results of screening for the potential antagonistic activity against important pathogens showed ZA3 exhibit broad-spectrum activity against a wide range of microorganisms, including gram-positive and gram-negative bacteria. Additionally, because the intestinal flora is a complex system and it is difficult to introduce new microorganisms into this competitive environment, it produces substances, such as bacteriocins, organic acids, short-chain fatty acids, and hydrogen peroxide that inhibit pathogens in the gut of growth, and reduce the occurrence of diarrhea [28]. ZA3 had strong antimicrobial activity after excluding the effects of hydrogen peroxide by proteinase $K$ and eliminating hydrogen peroxide from the cell-free culture supernatants; however, all activities disappeared completely when the cell-free supernatant was treated with neutralizing $\mathrm{pH}$, which indicated that the antimicrobial activity may be attributed to the production of organic acids. Similarly, as one of the antimicrobial compounds, Tirloni et al. [29] and Bah et al. [30] proposed organic acids can significantly inhibit the growth of pathogenic bacteria. Silva et al. [31] reported L. lactis subsp. lactis presented antimicrobial activity against pathogens, which may be related to their lactic acid production, low $\mathrm{pH}$ values, and antimicrobial compounds. Furthermore, some research results showed that the main organic acids metabolites of LAB fermentation were pyruvate, lactic acid, acetic acid, citric acid, oxalic acid, and malic acid etc. [29,32,33]. ZA3 mainly produced four kinds of organic acids: citric acid, succinic acid, lactic acid, and acetic acid, after $24 \mathrm{~h}$ fermentation, respectively. Lactic acid and acetic acid were significantly higher than other two acids. Such a conclusion is the same as that by Mun et al. [34], who researched lactic acid and acetic acid in L. plantarum fermentation broth as the main antibacterial active substances. In summary, it is worthwhile to investigate ZA3's effect on diarrhea in animals induced by ETEC K88. 


\section{Materials and Methods}

\subsection{Screening of LAB Restrain ETEC K88 Activity}

More than 1100 LAB strains isolated from weaned piglet feces, feed grass, Qula, rice silage, mixture silage, and corn silage were used in this study. All LAB isolates were incubated in de Man Rogosa Sharpe (MRS) broth at $30^{\circ} \mathrm{C}$.

Bacterial strains used in this article are shown in Table 8. Among which, ETEC K88 Salmonella enterica ATCC $43971^{\mathrm{T}}$ and Enterococcus faecalis ATCC $29212^{\mathrm{T}}$ were purchased from the China Veterinary Culture Collection Center (CVCC), China General Microbiological Culture Collection Center (CGMCC), and China Center of Industrial Culture Collection (CICC), respectively. Staphylococcus aureus ATCC $6538^{\mathrm{T}}$, Bacillus subtilis ATCC $19217^{\mathrm{T}}$, Escherichia coli ATCC $11775^{\mathrm{T}}$, Listeria monocytogenes ATCC $51719^{\mathrm{T}}$, Pseudomonas aeruginosa ATCC $15692^{\mathrm{T}}$, and Micrococcus luteus ATCC $4698^{\mathrm{T}}$ were stored in the laboratory.

Table 8. Information of bacterial strains in this article.

\begin{tabular}{|c|c|c|c|}
\hline Strain & Source & Strain & Source \\
\hline ETEC K88 & CVCC & Salmonella enterica ATCC $43971^{\mathrm{T}}$ & CGMCC \\
\hline Staphylococcus aureus ATCC $6538^{\mathrm{T}}$ & Store in laboratory & B. subtilis ATCC $19217^{\mathrm{T}}$ & Store in laboratory \\
\hline Escherichia coli ATCC $11775^{\mathrm{T}}$ & Store in laboratory & Listeria monocytogenes ATCC $51719^{\mathrm{T}}$ & Store in laboratory \\
\hline P. aeruginosa ATCC $15692^{\mathrm{T}}$ & Store in laboratory & M. luteus ATCC $4698^{\mathrm{T}}$ & Store in laboratory \\
\hline Enterococcus faecalis ATCC $29212^{\mathrm{T}}$ & CICC & & \\
\hline
\end{tabular}

Notes: 1. CVCC, China Veterinary Culture Collection Center; CGMCC, China General Microbiological Culture Collection Center; CICC, China Center of Industrial Culture Collection; 2. B. subtilis: Bacillus subtilis ATCC 19217' P. aeruginosa: Pseudomonas aeruginosa ATCC $15692^{\mathrm{T}}$; M. luteus: Micrococcus luteus ATCC $4698^{\mathrm{T}}$; E. faecalis: faecalis ATCC $29212^{\mathrm{T}}$.

The antagonistic effect of LAB isolates against ETEC K88 were first determined by the agar well diffusion technique [35]. The target bacteria ETEC K88 was grown in Luria-Bertani (LB) liquid culture medium and incubated at $37^{\circ} \mathrm{C}$ with $180 \mathrm{rpm}$ for $12 \mathrm{~h}$. Subsequently, $100 \mathrm{uL}$ of the overnight culture of $\mathrm{K} 88$ was added to LB agar medium, cooled to $50^{\circ} \mathrm{C}$, and shaken, mixing well before pouring onto the surface of the already coagulated LB agar plates. After solidification, $200 \mu \mathrm{L} 16 \mathrm{~h}$ cultures of different strains were placed in the hole punched in the center of the plate by using a hole puncher (diameter $10.00 \mathrm{~mm}$ ), with uninoculated MRS broth as negative, and penicillin (pc) as a positive control, respectively. Inhibition zone was measured after $2 \mathrm{~h}$ diffusion at $4{ }^{\circ} \mathrm{C}$.

\subsection{Molecular Identification of Representative Strains}

\subsubsection{S rRNA Analysis}

The 16S rRNA gene of selected strains were amplified by PCR using the $27 \mathrm{~F}$ (5'-AGAGT TTGATCCTGGCTCAG-3') and 1492 R (5'-GGTTACCTTGTTACGACTT-3') universal primer sets. Amplifications by PCR were performed in a total volume of $50 \mu \mathrm{L}$ DNA thermal cycler, which contained $25 \mu \mathrm{L} 2 \times$ Taq Plus Mastermix, $27 \mathrm{~F}$ and $1492 \mathrm{R}$ primer $1 \mu \mathrm{L}$ each, and finally add sterile distilled water and fix to $50 \mu \mathrm{L}$. Single colonies cultured for $24 \mathrm{~h}$ were added to each reaction system, separately, and the PCR condition was: initial activation at $94{ }^{\circ} \mathrm{C}$ for $5 \mathrm{~min} ; 33$ cycles at $94{ }^{\circ} \mathrm{C}$ for $50 \mathrm{~s}, 52{ }^{\circ} \mathrm{C}$ for $50 \mathrm{~s}$ and $72{ }^{\circ} \mathrm{C}$ for $50 \mathrm{~s}$; and a final cycle at $72{ }^{\circ} \mathrm{C}$ for $17 \mathrm{~min}$. The PCR products were placed in a $1 \%$ agarose gel and electrophoresed with Ethidium Bromide (EB) solution staining. The successful amplification was analyzed by sequencing service (MGI Tech Co., Ltd., Beijing, China), and resulting sequences were compared with sequences in the GenBank database using the BLAST program available on the National Center for Biotechnology Information website (http://www.ncbi.nlm.nih.gov).

\subsubsection{RecA Multiple Sequence}

Means of partial amplification product comparison of the recA gene was used to distinguish strains of L. plantarum cluster, including L. casei, L. paraplantarum, L. pentosus, L. plantarum subsp. 
plantarum, and L. plantarum subsp. argentoratensis [17]. A multiplex PCR assay $(20 \mu \mathrm{L})$ was performed with recA gene-based primers para $\mathrm{F}$ (5'-GTCACAGGCATTACGAA AAC-3'), pent $\mathrm{F}$ (5'-CAGTGGCGCGGTTGATATC-3'), plan F (5'-CCGTTTATGCGGAACACC TA-3'), and pREV (5'-TCGGGATTACCAAACATCAC-3'). The PCR mixture was composed of primers para F, pent F, and pREV ( $0.25 \mu \mathrm{M}$ each), $0.12 \mu \mathrm{M}$ primer plan F, $25 \mu \mathrm{L} 2 \times$ Taq Plus Mastermix, add sterile distilled water to $40 \mu \mathrm{L}$. Single colonies including type strains L. casei JCM $16167^{\mathrm{T}}$ (negative control), L. paraplantarum JCM $12533^{\mathrm{T}}$, L. pentosus JCM $1558^{\mathrm{T}}$, L. plantarum subsp. plantarum JCM $1149^{\mathrm{T}}$, and L. plantarum subsp. argentoratensis JCM $16169^{\mathrm{T}}$, and strains of this cluster, indistinguishable after $16 \mathrm{~S}$ rRNA analysis, were added to each reaction system, separately. The PCR condition was initial denaturation at $94{ }^{\circ} \mathrm{C}$ for $5 \mathrm{~min}, 33$ cycles of denaturation at $94{ }^{\circ} \mathrm{C}(30 \mathrm{~s})$, annealing at $56^{\circ} \mathrm{C}(10 \mathrm{~s})$, elongation at $72{ }^{\circ} \mathrm{C}(30 \mathrm{~s})$, and final extension at $72{ }^{\circ} \mathrm{C}$ for $5 \mathrm{~min}$. The PCR products were visualized in a $2 \%$ agarose gel in $0.5 \times$ TAE (20 mM Tris-acetate, 0.5 mM EDTA, pH 8.0) buffer.

\subsection{Cell Surface Hydrophobicity and Auto-aggregation of Representative Strains}

The cell surface hydrophobicity and auto-aggregation assay were performed according to Somashekaraiah et al. [20] and Wang et al. [36], respectively, and both with some modifications. LAB strains cultivated in MRS broth at $30^{\circ} \mathrm{C}$ for $16 \mathrm{~h}$ were washed twice with phosphate-buffered saline (PBS) $\left(8000 \times g, 4{ }^{\circ} \mathrm{C}, 10 \mathrm{~min}\right)$ and resuspended in PBS buffer followed by absorbance measurement at $600 \mathrm{~nm}$ (OD 600, marked as A0).

For cell surface hydrophobicity analysis, $3 \mathrm{~mL}$ cell suspension was blended with $1 \mathrm{~mL}$ xylene; the two-phase system was mixed by vortexing for $2 \mathrm{~min}$, and incubated at $37^{\circ} \mathrm{C}$ without shaking for $30 \mathrm{~min}$ (for separation of the aqueous and organic phases). The water phase was carefully removed and its absorbance at $600 \mathrm{~nm}$ was measured (OD 600, marked as A1). The percentage of cell surface hydrophobicity $(\mathrm{H} \%)$ was calculated using the following formula:

$$
{ }^{\prime} \mathrm{H} \%=(1-\mathrm{A} 1 / \mathrm{A} 0) \times 100 \%
$$

As for auto-aggregation, bacterial cell suspensions were mixed by vortexing for $10 \mathrm{~s}$ and incubated at room temperature for $8 \mathrm{~h}$, the upper suspension was checked for absorbance at $600 \mathrm{~nm}$ at time intervals of 0,2 , and $8 \mathrm{~h}$ (OD 600, the absorbance at each particular time marked as different Atime). The auto-aggregation was measured (in percentage) using the following formula:

$$
\text { auto-aggregation } \%=[1-(\text { Atime } / \mathrm{A} 0) \times 100] \%
$$

\subsection{Determination of Growth Curve and Acid Production Capacity of Representative Strains}

Each single LAB colony was picked and added into $20 \mathrm{~mL}$ sterile MRS, and the optical density at $600 \mathrm{~nm}$ (OD 600) and colony forming units (CFU) / $\mathrm{mL}$ were determined immediately at 2, 4, 6, $8,10,12,14,16,18,20,22$, and $24 \mathrm{~h}$ after inoculation at 30 and $39^{\circ} \mathrm{C}$, respectively. The $\mathrm{pH}$ of each fermentation solution was determined at $0,6,12,18,24,30,36,42$, and $48 \mathrm{~h}$ after inoculation at $30^{\circ} \mathrm{C}$ and $39^{\circ} \mathrm{C}$, respectively.

\subsection{Low $p H$ and Bile Salt Tolerance of Representative Strains}

MRS broth at $\mathrm{pH} 2.5$ and MRS solution containing $0.5 \%(w t / v o l)$ bile salt were used to assess low $\mathrm{pH}$ and bile salt tolerance, and $\mathrm{pH} 6.8$ and no bile salt MRS broth were set as control, respectively. Each LAB isolate was incubated at $30^{\circ} \mathrm{C}$ and $39^{\circ} \mathrm{C}$ in different acidic and bile salt environments for $0,2,4$, and $6 \mathrm{~h}$, respectively, and then incubated at $30^{\circ} \mathrm{C}$ for $20 \mathrm{~h}$, measuring the biomass by optical density at $600 \mathrm{~nm}$. 


\subsection{Survival of Representative Strains in GI Fluids}

The simulated gastric fluid (SGF) and simulated intestinal fluid (SIF) were performed as described by Massounga et al. [37] with modifications. Briefly, for SGF, $3.5 \mathrm{~g} / \mathrm{L}$ pepsin was suspended in $0.2 \%$ $\mathrm{w} / \mathrm{v}$ sterile $\mathrm{NaCl}$ solution and adjusted $\mathrm{pH}$ to 2.0, made the total volume of the solution up to $100 \mathrm{~mL}$, and filtered through a $0.22 \mu \mathrm{m}$ filter membrane. For SIF, $1 \mathrm{~g} / \mathrm{L}$ trypsin, $18 \mathrm{~g} / \mathrm{L}$ bile salt from ox and $11 \mathrm{~g} / \mathrm{L} \mathrm{NaHCO}_{3}$ were suspended in $0.2 \% \mathrm{w} / \mathrm{v}$ sterile $\mathrm{NaCl}$ solution, adjusted the $\mathrm{pH}$ of the solution 6.8 , and, again, brought the total solution volume to $100 \mathrm{~mL}$ with $0.22 \mu \mathrm{m}$ membrane filtration. Moreover, $2 \% 10^{8} \mathrm{CFU} / \mathrm{mL}$ LAB solution was added to $20 \mathrm{~mL} \mathrm{SGF}$ and incubated for $3 \mathrm{~h}$ (SIF was $4 \mathrm{~h}$ ). Viable colonies were determined with plate counts on MRS agar after 0,3 , and $7 \mathrm{~h}$ incubation.

\subsection{Pathogenicity Evaluation of Strain ZA3}

\subsubsection{Safety Evaluation}

The strain ZA3 was screened for the presence of genetic traits related to virulence factors, biogenic amines, and antibiotic resistance using the PCR protocols [38], and referring to the approach of Shankar et al. [39]. Enterococcus faecalis ATCC $29212^{\mathrm{T}}$ that harbor the target virulence genes (ace, cylA, and gelE) was used as positive control, and Milli-Q water as positive control, respectively. The target genes include gelE (gelatinase) (F: 5' -TATGACAATGCTTTTTGGGAT-3' , R: 5' -AGATGCACCCG AAATAATATA-3'), cylA (cytolysin) (F: 5' -GAATTGAGCAAAAGTTCAATCG-3' , R: 5' -GTCTGTCTT TTCACTTGTTTC-3'), ace (adhesion of collagen) (F: 5'-ACTCGGGGATTGATAGGC-3' , R: 5' -GCTGC TAAAGCTGCGCTT-3'), vanA (vancomycin resistance) (F: 5' -TCTGCAATA GAGATAGCCGC-3' , R: 5'-GGAGTAGCTATCCCAGCATT-3'), tetM (tetracycline resistance) (F: 5'-ATTACACTTCCGATTT CGG-3', R: 5'-GTTAAATAGTGTTCTTGGAG-3'), hdc (histidine decarboxylase) (F: 5' -AGATGGTAT TGTTTCTTATG-3', R: 5'-AGACCATACACCATAACCTT-3'), tdc (tyrosine decarboxylase) (F: 5' -GA YATNATNGGNATNGGNYTNGAYCARG-3' , R: 5' -CCRTARTCNGGNATAGCRAARTCNGTRTG-3'), and odc (ornithine decarboxylase) (F: 5'-GTNTTYAAYG CNGAYAARCANTAYTTYGT-3', R: 5' -ATNG ARTTNAGTTCRCAYTTYTCNG GG-3').

\subsubsection{Antibiotic Susceptibility}

The minimum inhibitory concentration (MIC, $\mu \mathrm{g} / \mathrm{mL}$ ) of 10 antibiotics was determined by agar dilution method according to the Clinical and Laboratory Standards Institute (CLSI) standards. Each experiment was performed on MRS agar plates containing different antibiotics, including carbenicillin, cefamezin, ampicillin, gentamicin, norfloxacin, clindamycin, penicillin, erythromycin, chloramphenicol, and amikacin. Antibiotics were prepared at a range of concentrations from 0.125 to $512 \mu \mathrm{g} / \mathrm{mL}$ by twofold dilution, and each concentration was tested in triplicate. All isolates were inoculated on MRS agar containing antibiotics at $37^{\circ} \mathrm{C}$ for $24 \mathrm{~h}$, and strains cultivated on MRS agar plates without antibiotics were used as controls.

\subsubsection{Hemolytic Activity}

Hemolytic activity was analyzed on blood agar as the manufacturer's instructions. Fresh bacterial ZA3 was streaked on Columbia blood agar plates, and Staphylococcus aureus ATCC6538 ${ }^{\mathrm{T}}$ was used as positive control.

\subsubsection{Toxicity Test of the ZA3 Strain against Eukaryotic Cells}

Cell viability was determined by the Cell Counting Kit-8 (CCK-8) assay (Nanjing Jiancheng Institute of Bioengineering, Nanjing, China). The experiment was divided into normal cell and LAB treatment groups, and the multiplicity of infection (MOI) was set to three gradients, 1, 2, and 3, with each well performed in sextuplicate. IPEC-J2 cells $\left(1 \times 10^{5}\right.$ cells/well) were seeded into 96-well tissue culture plates with $100 \mu \mathrm{L}$ per well. After cells grown in a humidified chamber at $37^{\circ} \mathrm{C}$ under 
$5 \% \mathrm{CO}_{2}$, collected that it reached $80 \%$ confluence, CCK-8 was used to stain the cells for about 2, 4, 12, and $24 \mathrm{~h}$ after being treated by ZA3, respectively. The optical density was measured at $450 \mathrm{~nm}$ using a microplate spectrophotometer.

$$
\text { Cell viability rate }=((\mathrm{As}-\mathrm{Ab}) /(\mathrm{Ac}-\mathrm{Ab})) \times 100 \%
$$

As: experimental well (including cell-containing medium, CCK-8 and ZA3);

Ac: control well (including cell-containing medium and CCK-8);

Ab: blank well (cell culture medium without cells, CCK-8).

\subsection{Antimicrobial Activity}

The antimicrobial activity of ZA3 against pathogenic bacteria was assessed by the method of agar well diffusion, E. coli ATCC $11775^{\mathrm{T}}$, Pseudomonas aeruginosa ATCC $15692^{\mathrm{T}}$, Staphylococcus aureus ATCC $6538^{\mathrm{T}}$, Bacillus subtilis ATCC $19217^{\mathrm{T}}$, Listeria monocytogenes ATCC $51719^{\mathrm{T}}$, Micrococcus luteus ATCC $4698^{\mathrm{T}}$, and Salmonella enterica ATCC $43971^{\mathrm{T}}$ were used as indicator bacterium.

\subsection{Carbohydrate Utilization Patterns of ZA3}

Thirty common carbon sources, including glycerol, D-arabinose, L-arabinose, ribose, D-xylose, galactose, D-glucose, D-fructose, mannose, L-sorbose, rhamnose, dulcitol, inositol, mannitol, sorbitol, salicin, cellobiose, maltose, lactose, melibiose, saccharose, trehalose, melezitose, D-raffinose, starch, xylitol, L-arabitol, gluconate, $\mathrm{N}$-acetyl glucosamine, and amygdalin were used to detect carbohydrate utilization patterns of ZA3 by replacing the carbon source, each in turn, in the MRS medium.

\subsection{Identification of the Antimicrobial Substance of $Z A 3$}

The antimicrobial substance of ZA3 was assessed according to $\mathrm{Ni}$ et al. [40] and exclusion experiments for acid and catalase inhibition, and protease (proteinase $K$, trypsin, and pepsin) degradation were performed, respectively. For the $\mathrm{pH}$ stability assay, the ZA3 bacteria suspension was adjusted to $\mathrm{pH}$ values ranging from 3.0 to 10.0 by $0.2 \mathrm{M} \mathrm{HCl}$ or $0.2 \mathrm{M} \mathrm{NaOH}$. For the hydrogen peroxide, the ZA3 bacteria suspension was treated with $0.5 \mathrm{mg} / \mathrm{mL}$ catalase to confirm if it had catalase inhibition. The effects of protease on antimicrobial activity were determined by incubating the ZA3 suspension, separately, with $1 \mathrm{mg} / \mathrm{mL}$ proteinase $\mathrm{K}$, trypsin, and pepsin at $37^{\circ} \mathrm{C}$ for $2 \mathrm{~h}$, and collecting the supernatant of overnight LAB cultures in MRS broth by centrifugation at $8000 \times g$ for $10 \mathrm{~min}$ to assay.

\subsection{Determination of Organic Acids Produced by ZA3}

The organic acid produced by ZA3 was determined with high performance liquid chromatography (HPLC) (column: Carbomix H-NP10: 8\%, 7.8 × 300 mm, Sepax Technologies, Inc., Newark, DE, USA; detector: DAD, 214 nm, Agilent 1200 Series, Agilent Technologies Co., MNC, Santa Clara, CA, USA; eluent: $2.5 \mathrm{mmol} / \mathrm{L} \mathrm{H}_{2} \mathrm{SO}_{4}, 0.6 \mathrm{~mL} / \mathrm{min}$; temperature: $55^{\circ} \mathrm{C}$ ). Overnight ZA3 bacteria cultures of LAB grown in MRS broth were centrifuged at $8000 \times g$ for $10 \mathrm{~min}$ and filtered through a $0.22 \mu \mathrm{m}$ filter membrane. The organic acids, lactic acid, acetic acid, propionic acid, butyric acid, succinic acid, citric acid, and malic acid were detected.

\subsection{Statistical Analyses}

Each test was performed in triplicate. Data were analyzed by one-way analysis of variance (ANOVA) or paired t-test (SPSS 22.0). All data were shown as mean \pm standard error of mean (SEM), and $p<0.05$ indicated significant difference in statistics. 


\section{Conclusions}

In this study, the inhibitory activities of $1100 \mathrm{LAB}$ strains from different sources were tested to inhibit ETEC K88. Of which, ZA3, isolated from weaned pig feces, and identified as L. plantarum subsp. plantarum, had good inhibition ability and growth performance, excellent safety features, as well as good hydrophobicity and auto-aggregation, high survival rate in SGF and SIF, broad-spectrum activity against a wide range of microorganisms, and antibacterial substance (which may be attributed to organic acids). Therefore, ZA3 might be a suitable candidate for further study, due to its protective effects against ETEC K88 infections in weaned piglets.

Author Contributions: H.P. and G.Q. designed experiments; W.W. carried out experiments; H.M., H.Y., Z.T. and Y.W. analyzed experimental results. W.W. and H.P. wrote the manuscript. All authors have read and agreed to the published version of the manuscript.

Funding: This work was supported by the Qinghai Province Key R\&D and Transformation Plan of China (No. 2020-NK-127).

Conflicts of Interest: The authors declare no conflict of interest. The sponsors had no role in the design, execution, interpretation, or writing of the study.

Data Availability Statement: The 16Sr RNA gene sequence of strains ZA3, ZA2, ZA28, ZA8, ZA10, ZA19, ZA33, ZA18, and ZA34 used to support the findings of this study have been deposited in the GenBank repository with accession number MT597900, MT597901, MT597902, MT597903, MT597904, MT597905, MT597906, MF597907, and MF597910, respectively.

\section{References}

1. Fleckenstein, J.M.; Kuhlmann, F.M. Enterotoxigenic Escherichia coli Infections. Curr. Infect. Dis. Rep. 2019, 21, 9. [CrossRef]

2. Kaper, J.B.; Nataro, J.P.; Mobley, H.L. Pathogenic Escherichia coli. Nat. Rev. Microbiol. 2004, 2, $123-140$. [CrossRef] [PubMed]

3. Rhouma, M.; Fairbrother, J.M.; Beaudry, F.; Letellier, A. Post weaning diarrhea in pigs: Risk factors and non-colistin-based control strategies. Acta. Vet. Scand. 2017, 59, 31. [CrossRef] [PubMed]

4. Zhang, H.; Xu, Y.; Zhang, Z.; You, J.; Yang, Y.; Li, X. Protective immunity of a multivalent vaccine candidate against piglet diarrhea caused by enterotoxigenic Escherichia coli (ETEC) in a pig model. Vaccine 2018, 36, 723-728. [CrossRef]

5. Kaevska, M.; Lorencova, A.; Videnska, P.; Sedlar, K.; Provaznik, I.; Trckova, M. Effect of sodium humate and zinc oxide used in prophylaxis of post-weaning diarrhoea on faecal microbiota composition in weaned piglets. Vet. Med. Czech. 2016, 61, 328-336. [CrossRef]

6. Sterndale, S.O.; Evans, D.J.; Mansfield, J.P.; Clarke, J.; Sahibzada, S.; Abraham, S.; O’Dea, M.; Miller, D.W.; Kim, J.C.; Pluske, J.R. Effect of mucin 4 allele on susceptibility to experimental infection with enterotoxigenic F4 Escherichia coli in pigs fed experimental diets. J. Anim. Sci. Biotechnol. 2019, 10, 56. [CrossRef]

7. Guerra-Ordaz, A.A.; Gonzalez-Ortiz, G.; La Ragione, R.M.; Woodward, M.J.; Collins, J.W.; Perez, J.F.; Martin-Orue, S.M. Lactulose and Lactobacillus plantarum, a potential complementary synbiotic to control postweaning colibacillosis in piglets. Appl. Environ. Microbiol. 2014, 80, 4879-4886. [CrossRef] [PubMed]

8. Sun, Y.; Kim, S.W. Intestinal challenge with enterotoxigenic Escherichia coli in pigs, and nutritional intervention to prevent postweaning diarrhea. Anim. Nutr. 2017, 3, 322-330. [CrossRef]

9. Mingmongkolchai, S.; Panbangred, W. Bacillus probiotics: An alternative to antibiotics for livestock production. J. Appl. Microbiol. 2018, 124, 1334-1346. [CrossRef]

10. Konstantinov, S.R.; Smidt, H.; Akkermans, A.D.; Casini, L.; Trevisi, P.; Mazzoni, M.; De Filippi, S.; Bosi, P.; de Vos, W.M. Feeding of Lactobacillus sobrius reduces Escherichia coli F4 levels in the gut and promotes growth of infected piglets. FEMS Microbiol. Ecol. 2008, 66, 599-607. [CrossRef] [PubMed]

11. Patil, A.K.; Kumar, S.; Verma, A.K.; Baghel, R.P.S. Probiotics as feed additives in weaned pigs: A Review. Livest. Res. Int. 2015, 3, 31-39. [CrossRef]

12. Zhang, L.; Xu, Y.; Liu, H.; Lai, T.; Ma, J.; Wang, J.; Zhu, Y. Evaluation of Lactobacillus rhamnosus GG using an Escherichia coli K88 model of piglet diarrhoea: Effects on diarrhoea incidence, faecal microflora and immune responses. Vet. Microbiol. 2010, 141, 142-148. [CrossRef] [PubMed] 
13. Sirichokchatchawan, W.; Pupa, P.; Praechansri, P.; Am-In, N.; Tanasupawat, S.; Sonthayanon, P.; Prapasarakul, N. Autochthonous lactic acid bacteria isolated from pig faeces in Thailand show probiotic properties and antibacterial activity against enteric pathogenic bacteria. Microb. Pathog. 2018, 119, 208-215. [CrossRef] [PubMed]

14. Dushku, E.; Ioannou, A.; Staikou, A.; Yiangou, M. Probiotic properties and immunomodulatory activity of gastrointestinal tract commensal bacterial strains isolated from the edible farmed snail Cornu aspersum maxima. Fish Shellfish Immun. 2019, 92, 792-801. [CrossRef] [PubMed]

15. Rao, Y.; Tao, Y.; Li, Y.; She, X.; Yang, J.; Qian, Y.; Du, H.; Liu, L.; Xiao, H. Characterization of a probiotic starter culture with anti-Candida activity for Chinese pickle fermentation. Food Funct. 2019, 10, 6936-6944. [CrossRef] [PubMed]

16. Wang, S.; Dong, Z.; Li, J.; Chen, L.; Shao, T. Pediococcus acidilactici strains as silage inoculants for improving the fermentation quality, nutritive value and in vitro ruminal digestibility in different forages. J. Appl. Microbiol. 2019, 126, 424-434. [CrossRef] [PubMed]

17. Pang, H.; Qin, G.; Tan, Z.; Li, Z.; Wang, Y.; Cai, Y. Natural populations of lactic acid bacteria associated with silage fermentation as determined by phenotype, $16 \mathrm{~S}$ ribosomal RNA and recA gene analysis. Syst. Appl. Microbiol. 2011, 34, 235-241. [CrossRef]

18. Dlamini, Z.C.; Langa, R.L.S.; Aiyegoro, O.A.; Okoh, A.I. Safety evaluation and colonisation abilities of four lactic acid bacteria as future probiotics. Probiotics Antimicro. 2019, 11, 397-402. [CrossRef]

19. Atassi, F.; Servin, A.L. Individual and co-operative roles of lactic acid and hydrogen peroxide in the killing activity of enteric strain Lactobacillus johnsonii NCC933 and vaginal strain Lactobacillus gasseri KS120.1 against enteric, uropathogenic and vaginosis-associated pathogens. FEMS Microbiol. Lett. 2010, 304, $29-38$. [CrossRef]

20. Somashekaraiah, R.; Shruthi, B.; Deepthi, B.V.; Sreenivasa, M.Y. Probiotic properties of lactic acid bacteria isolated from Neera: A naturally fermenting coconut palm nectar. Front. Microbiol. 2019, 10, 1382. [CrossRef]

21. Kumara, S.S.; Bashisht, A.; Venkateswaran, G.; Hariprasad, P.; Gayathri, D. Characterization of novel Lactobacillus fermentum from curd samples of indigenous cows from malnad region, Karnataka, for their aflatoxin B1 binding and probiotic properties. Probiotics Antimicro. 2019, 11, 1100-1109. [CrossRef] [PubMed]

22. Joghataei, M.; Shahidi, F.; Pouladfar, G.; Mortazavi, S.A.; Ghaderi, A. Probiotic potential comparison of Lactobacillus strains isolated from Iranian traditional food products and human feces with standard probiotic strains. J. Sci. Food Agric. 2019, 99, 6680-6688. [CrossRef] [PubMed]

23. Lee, K.W.; Shim, J.M.; Park, S.K.; Heo, H.J.; Kim, H.J.; Ham, K.S.; Kim, J.H. Isolation of lactic acid bacteria with probiotic potentials from kimchi, traditional Korean fermented vegetable. LWT Food Sci. Technol. 2016, 71, 130-137. [CrossRef]

24. Iannitti, T.; Palmieri, B. Therapeutical use of probiotic formulations in clinical practice. Clin. Nutr. 2010, 29, 701-725. [CrossRef] [PubMed]

25. Boyle, R.J.; Robins-Browne, R.M.; Tang, M.L. Probiotic use in clinical practice: What are the risks? Am. J. Clin. Nutr. 2006, 83, 1256-1264. [CrossRef]

26. Choudhary, J.; Dubey, R.C.; Sengar, G.; Dheeman, S. Evaluation of probiotic potential and safety assessment of Lactobacillus pentosus MMP4 isolated from Mare's lactation. Probiotics Antimicro. 2019, 11, 403-412. [CrossRef]

27. Nawaz, M.; Wang, J.; Zhou, A.; Ma, C.; Wu, X.; Moore, J.E.; Millar, B.C.; Xu, J. Characterization and transfer of antibiotic resistance in lactic acid bacteria from fermented food products. Curr. Microbiol. 2011, 62, 1081-1089. [CrossRef]

28. Fuller, R. Probiotics in man and animals: A review. J. Appl. Bacteriol. 1989, 365-378. [CrossRef]

29. Tirloni, E.; Bernardi, C.; Ghelardi, E.; Celandroni, F.; Andrighetto, C.; Rota, N.; Stella, S. Biopreservation as a potential hurdle for Bacillus cereus growth in fresh cheese. J. Dairy Sci. 2020, 103, 150-160. [CrossRef]

30. Bah, A.; Albano, H.; Barbosa, J.B.; Fhoula, I.; Gharbi, Y.; Najjari, A.; Boudabous, A.; Teixeira, P.; Ouzari, H.I. Inhibitory effect of Lactobacillus plantarum FL75 and Leuconostoc mesenteroides FL14 against foodborne pathogens in artificially contaminated fermented tomato juices. Biomed. Res. Int. 2019. [CrossRef]

31. Da Silva, L.A.; Lopes Neto, J.H.P.; Cardarelli, H.R. Safety and probiotic functionality of isolated goat milk lactic acid bacteria. Ann. Microbiol. 2019. [CrossRef]

32. Alan, Y.; Topalcengiz, Z.; Dığrak, M. Biogenic amine and fermentation metabolite production assessments of Lactobacillus plantarum isolates for naturally fermented pickles. LWT. 2018, 98, 322-328. [CrossRef] 
33. Wang, H.; Huang, Y.; Zhu, C. Effects of lactic acid bacteria fermentation on organic acids, volatile aroma components, and sensory quality of Hawthorn pulp. IOP Conf. Ser. Earth Environ. Sci. 2019, 267. [CrossRef]

34. Mun, S.Y.; Kim, S.K.; Woo, E.R.; Chang, H.C. Purification and characterization of an antimicrobial compound produced by Lactobacillus plantarum EM showing both antifungal and antibacterial activities. LWT. 2019, 114. [CrossRef]

35. Ziadi, M.; Bouzaiene, T.; Lakhal, S.; Zaafouri, K.; Massoudi, S.; Dousset, X.; Hamdi, M. Screening of lactic starter from Tunisian fermented vegetables and application for the improvement of caper (Capparis spinosa) fermentation through an experimental factorial design. Ann. Microbiol. 2019. [CrossRef]

36. Wang, J.; Wang, J.; Yang, K.; Liu, M.; Zhang, J.; Wei, X.; Fan, M. Screening for potential probiotic from spontaneously fermented non-dairy foods based on in vitro probiotic and safety properties. Ann. Microbiol. 2018, 68, 803-813. [CrossRef]

37. Massounga Bora, A.F.; Li, X.; Zhu, Y.; Du, L. Improved viability of microencapsulated probiotics in a freeze-dried banana powder during storage and under simulated gastrointestinal tract. Probiotics Antimicro. 2019, 11, 1330-1339. [CrossRef]

38. Kaktcham, P.M.; Tchamani Piame, L.; Sandjong Sileu, G.M.; Foko Kouam, E.M.; Temgoua, J.B.; Zambou Ngoufack, F.; de Lourdes Perez-Chabela, M. Bacteriocinogenic Lactococcus lactis subsp. lactis 3MT isolated from freshwater Nile Tilapia: Isolation, safety traits, bacteriocin characterisation, and application for biopreservation in fish pate. Arch. Microbiol. 2019, 9, 1249-1258. [CrossRef]

39. Shankar, N.; Lockatell, C.V.; Baghdayan, A.S.; Drachenberg, C.; Gilmore, M.S.; Johnson, D.E. Role of Enterococcus faecalis surface protein esp in the pathogenesis of ascending urinary tract infection. Infect. Immun. 2001, 69, 4366-4372. [CrossRef]

40. Ni, K.; Yang, H.; Hua, W.; Wang, Y.; Pang, H. Selection and characterisation of lactic acid bacteria isolated from different origins for ensiling Robinia pseudoacacia and Morus alba L. leaves. J. Integr. Agric. 2016, 15, 2353-2362. [CrossRef]

(C) 2020 by the authors. Licensee MDPI, Basel, Switzerland. This article is an open access article distributed under the terms and conditions of the Creative Commons Attribution (CC BY) license (http://creativecommons.org/licenses/by/4.0/). 